medRxiv preprint doi: https://doi.org/10.1101/2021.02.28.21252516; this version posted March 2, 2021. The copyright holder for this preprint

(which was not certified by peer review) is the author/funder, who has granted medRxiv a license to display the preprint in perpetuity.

All rights reserved. No reuse allowed without permission.

\title{
1 Electrocardiographic Manifestations of Immune Checkpoint Inhibitor Myocarditis
}

2 John R Power ${ }^{1}$, Joachim Alexandre ${ }^{2}$, Arrush Choudhary ${ }^{1}$, Benay Ozbay ${ }^{3}$, Salim Hayek ${ }^{4}$, Aarti 3 Asnani $^{5}$, Yuichi Tamura ${ }^{6}$, Mandar Aras ${ }^{7}$, Jennifer Cautela ${ }^{8}$, Franck Thuny ${ }^{8}$, Lauren Gilstrap ${ }^{9}$, 4 Dimitri Arangalage ${ }^{10}$, International ICI-myocarditis registry, Steven Ewer ${ }^{11}$, Shi Huang ${ }^{1}$, Anita 5 Deswal $^{12}$, Nicolas L. Palaskas ${ }^{12}$, Daniel Finke ${ }^{13}$, Lorenz Lehman ${ }^{13}$, Stephane Ederhy ${ }^{14}$, Javid 6 Moslehi $^{1 \text { \#\# }}$, Joe-Elie Salem ${ }^{14 \#}$

Vanderbilt Univ Medical Ctr, Nashville, TN

Univ Caen Normandie, Caen, France

Basaksehir Cam and Sakura State Hospital, Istanbul, Turkey

Univ of Michigan, Ann Arbor, MI

Beth Israel Deaconess Medical Center, Boston, MA

Intl Univ of Health and Welfare Mita Hosp, Tokyo, Japan

Univ of California San Francisco, San Francisco, CA

APHM- Hôpital Nord, Marseille, France

Dartmouth Hitchcock Medical Ctr, Lebanon, NH

Hôpital Bichat, Paris, France

Univ of Wisconsin Hosp, Madison, WI

UT MD Anderson Cancer Ctr, Houston, TX

Univ of Heidelberg, Heidelberg)

APHP.Sorbonne Université, Paris, France 
8 Collaborators (International ICI-myocarditis registry):

9 Baptiste Abbar ${ }^{14}$, Yves Allenbach ${ }^{14}$, Tariq U Azam ${ }^{4}$, Alan Baik ${ }^{7}$, Lauren A Baldassarre ${ }^{15}$, 10 Barouyr Baroudjian ${ }^{16}$, Pennelope Blakley ${ }^{4}$, Sergey Brodsky ${ }^{17}$, Johnny Chahine ${ }^{18}$, Wei-Ting $11 \mathrm{Chan}^{19}$, Amy Copeland ${ }^{20}$, Shanthini M Crusz ${ }^{21}$, Grace Dy ${ }^{22}$, Charlotte Fenioux ${ }^{14}$, Kambiz 12 Ghafourian $^{23}$, Arjun K Ghosh ${ }^{21}$, Valérie Gounant ${ }^{10}$, Avirup Guha ${ }^{17,24}$, Manhal Habib ${ }^{25}$, Osnat 13 Itzhaki Ben Zadok ${ }^{26}$, Lily Koo Lin ${ }^{27}$, Michal Laufer-Perl ${ }^{28}$, Carrie Lenneman ${ }^{29}$, Darryl Leong ${ }^{30}$, 14 Matthew Martini ${ }^{11}$, Tyler Meheghan ${ }^{5}$, Elvire Mervoyer $^{31}$, Cecilia Monge ${ }^{32}$, Ryota Morimoto ${ }^{33}$, 15 Ana Narezkina ${ }^{34}$, Martin Nicol ${ }^{35}$, Joseph Nowatzke ${ }^{1}$, Olusola Ayodeji Orimoloye ${ }^{1}$, Milan Patel ${ }^{15}$, 16 Daniel Perry ${ }^{4}$, Nicolas Piriou ${ }^{36}$, Lawrence Piro ${ }^{37}$, Tyler Moran ${ }^{38}$, Ben Stringer ${ }^{39}$, Kazuko Tajiri ${ }^{40}$, 17 Pankit Vachhani ${ }^{29}$, Ellen Warner ${ }^{41}$, Marie-Claire Zimmer ${ }^{42}$

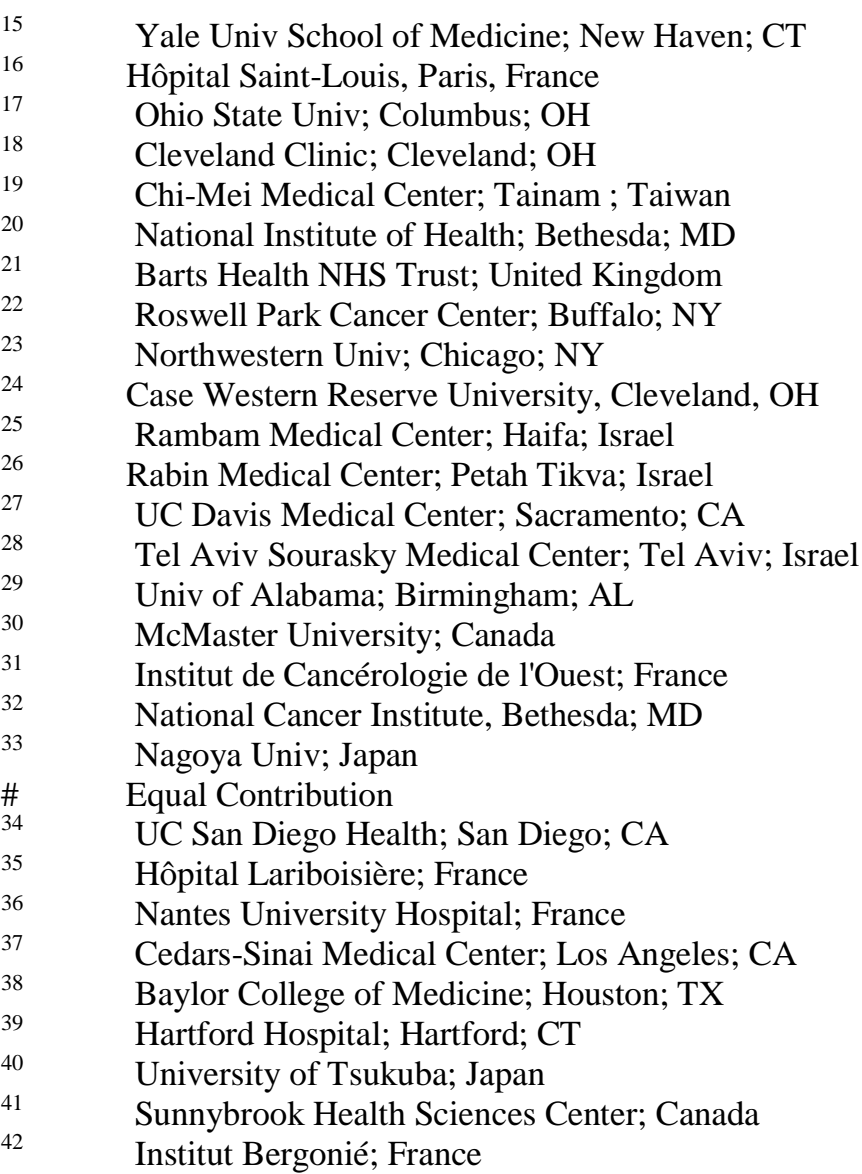


medRxiv preprint doi: https://doi.org/10.1101/2021.02.28.21252516; this version posted March 2, 2021. The copyright holder for this preprint (which was not certified by peer review) is the author/funder, who has granted medRxiv a license to display the preprint in perpetuity. All rights reserved. No reuse allowed without permission.

18 Contact Information: Javid Moslehi, M.D. Cardio-Oncology Program, Vanderbilt University

19 Medical Center, 2220 Pierce Avenue, Nashville, TN 37232, Phone: 615-343-9436; Fax: 615-

20 936-1872; Email: javid.moslehi@ vumc.org or Joe-Elie Salem, M.D., Ph.D, Centre

21 d'Investigation Clinique Paris-Est, Hôpital Pitié-Salpêtrière, Bâtiment Antonin Gosset, 47-83 Bld

22 de l'hôpital, 75013 Paris, France. Secretariat: +33 1421785 31, Fax: +33 1421785 32; Email:

23 joe-elie.salem@aphp.fr.

25 Word counts (Text; abstract): 2998/3000; 334/350

26 (2 Figures + 3 Tables)/(5 Tables and/or Figures), 4 Supplemental Figures, 6 Supplemental

27 Tables, 2 Supplemental Data Methods Sections)

28 Disclosures: JES have participated to BMS ad-boards and consultancy for AstraZeneca. JM has

29 served on advisory boards for Bristol Myers Squibb, Takeda, Regeneron, Audentes, Deciphera,

30 Ipsen, Janssen, ImmunoCore, Boston Biomedical, Amgen, Myovant, Triple Gene/Precigen,

31 Cytokinetics and AstraZeneca and supported by NIH grants (R01HL141466, R01HL155990,

32 R01HL156021). LHL has served on the advisory board for Daiichi Sankyio, Senaca, and Servier,

33 as an external expert for Astra Zeneca and received speakers' honoraria from Novartis and

34 MSD. SMC has received consultancy from GSK, speaker bureau from BMS, and travel grant

35 from Tesaro.

36 NCT: NCT04294771

37 Keywords: Myocarditis, cardio-oncology, immunotherapy, electrophysiology 


\section{Key Points}

$40 \quad$ (90/100 words)

41 Question: What are the electrocardiographic manifestations of immune checkpoint inhibitor

42 (ICI)-associated myocarditis? How do they compare to acute cellular rejection (ACR), which is

43 resembling pathophysiologically to ICI-myocarditis? Which electrocardiographic features are

44 associated with adverse outcomes?

45 Findings: ICI-myocarditis results in more frequent ventricular arrhythmias and high-degree

46 atrioventricular blocks compared to ACR. Prolonged QRS intervals, decreased voltage,

47 conduction disorders, and pathological Q-waves are predictors of adverse outcomes in ICI-

48 associated myocarditis.

49 Meaning: ICI-associated myocarditis is a highly arrhythmogenic cardiomyopathy. Ventricular

50 arrhythmias, conduction disorders, low-voltage, and pathological Q-waves are associated with a

51 poor prognosis. 
medRxiv preprint doi: https://doi.org/10.1101/2021.02.28.21252516; this version posted March 2, 2021. The copyright holder for this preprint (which was not certified by peer review) is the author/funder, who has granted medRxiv a license to display the preprint in perpetuity.

\section{Abstract (334/350 words)}

53 Importance: Immune-checkpoint inhibitor (ICI)-myocarditis often presents with arrhythmias,

54 but electrocardiographic (ECG) findings have not been well described. ICI-myocarditis and acute

55 cellular rejection (ACR) following cardiac transplantation share similarities on histopathology;

56 however, whether they differ in arrhythmogenicity is unclear.

57 Objectives: To describe ECG findings in ICI-myocarditis, compare them to ACR, and evaluate

58 their prognostic significance.

59 Design: Cases of ICI-myocarditis were retrospectively identified through a multicenter network.

60 Grade 2R or 3R ACR was retrospectively identified within one center. Two blinded cardiologists

61 interpreted ECGs.

62 Setting: 49 medical centers spanning 11 countries.

63 Participants: 147 adults with ICI-myocarditis, 50 adults with ACR.

64 Exposure: Myocarditis after ICI exposure per European Society of Cardiology criteria for

65 clinically suspected myocarditis, grade 2R or 3R ACR per the International Society for Heart and

66 Lung Transplantation working formulation for biopsy diagnosis of rejection.

67 Outcomes: All-cause mortality, myocarditis-related mortality; and composite endpoint (defined

68 as myocarditis-related mortality and life-threatening ventricular arrhythmia).

69 Results: Of 147 patients, the median age was 67 years (58-77) with 92 (62.6\%) men. At 30 days,

70 ICI-myocarditis had an all-cause mortality of 39/146(26.7\%), myocarditis-related mortality of

$7124 / 146(16.4 \%)$, and composite endpoint of 37/146(25.3\%). All-cause mortality was more

72 common in patients who developed complete heart block (12/25[48\%] vs 27/121[22.3\%], hazard

73 ratio $(\mathrm{HR})=2.62,95 \%$ confidence interval $[1.33-5.18], \mathrm{p}=0.01)$ or life-threatening ventricular 
74 arrhythmias $(12 / 22[55 \%]$ vs $27 / 124[21.8 \%], H R=3.10$ [1.57-6.12],p=0.001) within 30 days after

75 presentation. Compared to ACR, patients with ICI-myocarditis were more likely to experience

76 life-threatening ventricular arrhythmias $(22 / 147[16.3 \%]$ vs $1 / 50[2 \%] ; \mathrm{p}=0.01)$ or third-degree

77 heart block (25/147 [17.0\%] vs 0/50 [0\%];p=0.002). In ICI-myocarditis, overall mortality,

78 myocarditis-related mortality, and composite outcome adjusted for age and sex were associated

79 with pathological Q-waves on presenting ECG (hazard ratio by subdistribution model

$80[\mathrm{HR}(\mathrm{sh})]=5.98[2.8-12.79], \mathrm{p}<.001 ; 3.40[1.38-8.33], \mathrm{p}=0.008 ; 2.20[0.95-5.12], \mathrm{p}=0.07$;

81 respectively) but inversely associated with Sokolow-Lyon Index $(\mathrm{HR}(\mathrm{sh}) / \mathrm{mV}=0.57[0.34$ -

$820.94], \mathrm{p}=0.03 ; \mathrm{HR}(\mathrm{sh})=0.54[0.30-0.97], \mathrm{p}=0.04 ; 0.50[0.30-0.85], \mathrm{p}=0.01 ;$ respectively $)$. The

83 composite outcome was also associated with conduction disorders on presenting ECG

$84(\mathrm{HR}(\mathrm{sh})=3.27[1.29-8.34], \mathrm{p}=0.01)$.

85 Conclusions: ICI-myocarditis has more life-threatening arrhythmias than ACR and manifests as

86 decreased voltage, conduction disorders, and repolarization abnormalities . Ventricular

87 tachycardias, complete heart block, low-voltage, and pathological Q-waves were associated with

88 adverse outcomes. 
medRxiv preprint doi: https://doi.org/10.1101/2021.02.28.21252516; this version posted March 2, 2021. The copyright holder for this preprint (which was not certified by peer review) is the author/funder, who has granted medRxiv a license to display the preprint in perpetuity.

\section{Introduction}

Immune checkpoint inhibitors (ICI) have transformed oncology care with nearly $50 \%$ of

91 cancer patients eligible for ICI treatment. ${ }^{1}$ ICI unleash cytotoxic T-cells to achieve anti-tumor

92 effects but can also cause T-cell and macrophage mediated myocarditis. ${ }^{2-4}$ A subset of ICI

93 recipients $(0.3 \%$ to $1.1 \%)$ experience myocarditis, a rare immune related adverse event (IrAE)

94 that can cause cardiogenic shock and fatal arrhythmias. ${ }^{5,6}$ The diagnosis of ICI-myocarditis

95 remains challenging. ${ }^{2,7}$ Cardiac magnetic resonance imaging (cMRI) and endomyocardial biopsy

96 (EMB) are often difficult to obtain due to patients' critical condition. Furthermore, sensitivity of

97 cMRI is estimated at $48 \%$ with EMB also resulting in false negatives. ${ }^{8}$ A multimodal approach

98 incorporating biomarker, echocardiographic, and electrocardiographic (ECG) findings may

99 represent a high yield strategy in diagnosing ICI-related myocarditis. ${ }^{9}$ However, ECG findings in

100 ICI-myocarditis have yet to be systematically described and their prognostic significance has not

101 yet been studied.

102 We set out to describe presenting ECG and telemetry events in patients with ICI-

103 myocarditis given that arrhythmogenic events are routinely and easily identified in presenting

104 patients. We compared these findings to ECG from a cohort of heart transplant recipients

105 diagnosed with acute cellular rejection (ACR). We hypothesized that ICI-myocarditis would

106 mimic the low-voltage and QRS prolongation seen in ACR. ${ }^{4,10,11}$ This hypothesis was grounded

107 in the many pathologic similarities between ACR and ICI-myocarditis, including lymphocytic

108 infiltration, a similarity that has motivated the use of similar immunosuppressive treatment

109 strategies for both conditions, including corticosteroids and anti-T cell directed therapies. ${ }^{2-4,12-17}$

110 Additionally, we hypothesized that presenting ECG features in ICI-myocarditis would predict

111 death and life-threatening ventricular arrhythmias. 
medRxiv preprint doi: https://doi.org/10.1101/2021.02.28.21252516; this version posted March 2, 2021. The copyright holder for this preprint (which was not certified by peer review) is the author/funder, who has granted medRxiv a license to display the preprint in perpetuity.

\section{Methods}

\section{ICI-Myocarditis Selection}

114 A retrospective multicenter registry spanning 49 institutions across 11 countries was used to

115 collect 147 cases of ICI-myocarditis (Supplemental Table 1) as defined by European Society of

116 Cardiology criteria for clinically suspected myocarditis with recent ICI exposure. ${ }^{18}$ External

117 collaborating institutions were identified through cardio-oncology departments, via a website

118 created to collect cases of ICI-myocarditis (www.cardioonc.org), and by contacting authors of

119 published case reports (Supplementary Data Methods 1). Clinical data was collected and shared

120 by participating collaborators via a HIPPA-compliant REDCap web-based platform (IRB:

121 181337; NCT04294771). ${ }^{19,20}$ All 147 cases were analyzed for presence of arrhythmias

122 throughout hospitalization as reported by treating physicians. ECG on admission was

123 independently examined for 125 cases where ECG was obtained within 3 days of admission

124 (Supplemental Figure 1). When multiple presenting ECG were available, ECG closest to

125 presentation and without complete heart block or supraventricular arrhythmias were

126 preferentially selected. Baseline ECG was defined as the most recent ECG obtained before ICI

127 exposure and was available for independent examination in 52 cases.

128 ACR selection

129 Heart transplants at Vanderbilt University Medical Center complicated by grade $2 \mathrm{R}$ or $3 \mathrm{R}$

130 acute cellular rejection were selected in reverse chronological order and spanned 2013-2019. ${ }^{21}$

131 Cases of concomitant humoral rejection were excluded. ECG obtained less than 10 days after

132 heart transplantation or more than 3 days from diagnostic EMB were excluded. Donor and

133 recipient characteristics were collected via chart review and the Organ Procurement and

134 Transplantation Network database. 
medRxiv preprint doi: https://doi.org/10.1101/2021.02.28.21252516; this version posted March 2, 2021. The copyright holder for this preprint (which was not certified by peer review) is the author/funder, who has granted medRxiv a license to display the preprint in perpetuity.

\section{ECG Interpretation}

Two blinded cardiologists (BO, JA) systematically quantified standard ECG intervals

137 (PR, QRS, QTc, Sokoloff-Lyon Index) and evaluated for relevant qualitative features. ECG

138 features were aggregated on basis of pathophysiological relatedness (Supplemental Table 2).

139 Inter- and intra-observer variability was excellent (intra-class correlation>0.8) for PR, QRS, QTc

140 and Sokoloff measurements (Supplemental Data Methods 2).

\section{Statistical Analysis}

Paired t-test and McNemar's test were used to compare features of presenting ECG to

143 baseline ECG. Non-parametric Wilcoxon and Chi-squared test was used to compare ECG

144 features in ICI-myocarditis to ACR. The primary outcome was myocarditis-related mortality in

145 thirty days. The secondary outcomes were 1) a composite of either myocarditis-related death or

146 life-threatening arrhythmia in thirty days (defined as sustained ventricular tachycardia,

147 ventricular fibrillation, torsade de pointes, pulseless electrical activity, or asystole) and 2) all-

148 cause mortality in thirty days.

149 The primary outcome analysis used features on the presenting ECG as the independent

150 variable. Since our methodology preferentially selects for ECG that do not exclusively capture

151 heart block, life-threatening ventricular arrhythmias, or supraventricular arrhythmias, a focused

152 secondary analysis used the aggregate incidence of these arrhythmias throughout the entire

153 hospitalization as the independent variable to test association with outcomes of interest. In both

154 analyses, Cox proportional-hazards model determined association with all-cause mortality over

155 the 30-day surveillance period. Competing risk analysis (Subdistribution hazards model, i.e.,

156 Fine-Gray model) was used to account for mortality due to causes other than myocarditis for the

157 outcomes of myocarditis-related mortality or composite outcome. These models were separately 
medRxiv preprint doi: https://doi.org/10.1101/2021.02.28.21252516; this version posted March 2, 2021. The copyright holder for this preprint (which was not certified by peer review) is the author/funder, who has granted medRxiv a license to display the preprint in perpetuity. All rights reserved. No reuse allowed without permission.

158 adjusted for age and sex in a multivariable analysis. Hazard Ratio (HR), 95\% confidence

159 interval, and cumulative incidence curves were presented. 
medRxiv preprint doi: https://doi.org/10.1101/2021.02.28.21252516; this version posted March 2, 2021. The copyright holder for this preprint (which was not certified by peer review) is the author/funder, who has granted medRxiv a license to display the preprint in perpetuity.

\section{Results}

\section{Demographics}

The 147 patients with ICI-myocarditis had a median (IQR) age of 67 years (58-77) and

$16492 / 147(62.6 \%)$ were male (Table 1). Median days from first ICI dose to myocarditis

165 presentation was 38 days (21-83). In 146 patients with 30-day surveillance, 39/146 (26.7\%) died

166 within 30 days of presentation of which $24 / 39(62 \%)$ of deaths were attributable to myocarditis.

167 Other leading causes of death included to cancer progression - 6/39 (15\%), sepsis - 6/39 (15\%),

168 and non-cardiac IrAE 7/39 (18\%), of which 6/7 (86\%) were attributable to non-cardiac

169 myotoxicities (e.g., myositis). Pacemakers and/or defibrillators were placed in 22/146 (15.1\%)

170 patients within 30 days of presentation.

171 In total, 135/147 (91.8\%) patients experienced abnormal ECG during hospitalization.

172 Throughout hospitalization (median: 11 days, IQR:7-24), 101/147 (68.7\%) patients experienced

173 conduction disorders, which included second-degree heart block (11/147 (7.5\%)) and complete

174 heart block (25/147 (17.0\%)). Of note, supraventricular arrhythmias had a cumulative incidence

175 of $35 / 147(23.8 \%)$. A total of 22/147 (15.0\%) patients experienced life-threatening ventricular

176 arrhythmia, including 16/147 (10.9\%) sustained ventricular tachycardia, 4/147 (2.7\%) ventricular

177 fibrillation, 2/147 (1.4\%) torsade de pointes, 4/147 (2.7\%) pulseless electrical activity, and 4/147

178 (2.7\%) asystole. A total of 11/147 (7.5\%) patients developed both complete heart block and a

179 life-threatening ventricular arrhythmia.

180 Comparison to Baseline ECG

181 Baseline ECG obtained before ICI exposure was available for comparison in 52 cases.

182 Paired analysis comparing presenting ECG to baseline ECG showed ICI-myocarditis presents

183 with elevated heart rate (93.9 vs 80.4 bpm;p=0.009) and prolongation of QRS (95.3 vs 93.2 
medRxiv preprint doi: https://doi.org/10.1101/2021.02.28.21252516; this version posted March 2, 2021. The copyright holder for this preprint (which was not certified by peer review) is the author/funder, who has granted medRxiv a license to display the preprint in perpetuity.

All rights reserved. No reuse allowed without permission.

$184 \mathrm{~ms} ; \mathrm{p}=0.02$ ) and QT interval corrected for heart rate using Fridericia's formula (441.8 vs 421.0

$185 \mathrm{~ms} ; \mathrm{p}=0.03$ ) ( Table 2). There was a significant decrease in cardiac depolarization voltage assessed

186 by the quantitative Sokolow-Lyonn Index (1.39 vs $1.69 \mathrm{mV} ; \mathrm{p}=0.006)$. The incidence of left

187 bundle branch block (LBBB) $(10 / 52[19 \%]$ vs 3/52 [6\%];p=0.046) and sinus tachycardia $(25 / 52$

188 [48\%] vs 15/52 [29\%]; $\mathrm{p}=0.02)$ were increased from baseline. In aggregate, conduction disorders

$189(35 / 52[67 \%]$ vs 23/52 [44\%];p=0.01) and repolarization abnormalities (27/52 [52\%] vs 13/52

$190[25 \%], \mathrm{p}=0.008)$ were significantly increased. Of note, ECG suggestive of pericarditis were

191 infrequent without significant increase from baseline $(4 / 52$ [8\%] vs $1 / 52$ [2\%],p=0.25).

192

\section{Outcome Analysis by Cumulative Incidence of Arrhythmia}

193 Patients with ICI-myocarditis were more likely to experience all-cause mortality within

19430 days if they developed complete heart block (12/25 [48\%] vs 27/122 [22.1\%]; HR=2.62, 95\%

195 confidence interval=[1.33-5.18],p=0.01) or life-threatening ventricular arrhythmias $(12 / 22$ [55\%]

196 vs 27/125 [21.6\%]; HR=3.10 [1.57-6.12],p=0.001) at any point during hospitalization (

197 cumulative incidence curves in Figure 1).

198 Additionally, myocarditis-related mortality within 30 days was more common in patients

199 who developed complete heart block (8/25 [32\%] vs 16/122 [13.1\%]; hazard ratio by

200 subdistribution model[HR(sh)=2.73 [1.18-6.32],p=0.019) or life-threatening ventricular

201 arrhythmias $(10 / 22$ [45.5\%] vs 14/125 [11.2\%]; HR(sh)=4.98 [2.24-11.1],p<0.001) (cumulative

202 incidence curves in Figure 1).

203 Composite outcome of myocarditis-related mortality or life-threatening ventricular

204 arrhythmia within 30 days was also more common in patients who experienced complete heart

205 block $(13 / 25$ [52\%] vs 24/122 [19.7\%]; HR(sh)=3.55 [1.80-6.99],p<0.001) (figure not shown). 
medRxiv preprint doi: https://doi.org/10.1101/2021.02.28.21252516; this version posted March 2, 2021. The copyright holder for this preprint (which was not certified by peer review) is the author/funder, who has granted medRxiv a license to display the preprint in perpetuity.

All rights reserved. No reuse allowed without permission.

Supraventricular arrhythmia at any point during hospitalization was not associated with

either all-cause mortality (13/35 [37\%] vs 26/112 [23.2\%]; HR=1.67 [0.86-3.25],p=0.13),

myocarditis-related mortality $(8 / 35[22.9 \%]$ vs $16 / 112$ [14.3\%]; $\mathrm{HR}(\mathrm{sh})=1.61[0.71-3.7], \mathrm{p}=0.26)$,

209 or composite outcome within 30 days $(13 / 35$ [37.1\%] vs 24/112 [21.4\%]; HR(sh)=1.72 [0.91-

210 3.26],p=0.10) (cumulative incidence curves in Supplemental Figure 2).

\section{Outcome Analysis by Presenting ECG Features}

A total of 125 ICI-myocarditis patients met criteria to be included in the analysis of

213 predictive value of presenting ECG features and 22 were excluded due to initial ECG obtained

214 more than 3 days from admission or initial ECG with paced rhythm or exclusively capturing

215 ventricular tachycardia (flow chart of analyzed ECG in Supplemental Figure 1, characteristics of

216 the population in Supplemental Table 3). Using survival analyses, thirty-day myocarditis-related

217 mortality was significantly associated with pathological Q-waves (7/19 [37\%] vs 13/106

$218 \quad[12.3 \%] ; \mathrm{HR}(\mathrm{sh})=3.67$ [1.46-9.22],p=0.006) and low QRS voltage $(3 / 6$ [50\%] vs 17/119

$219 \quad[14.3 \%] ; \mathrm{HR}(\mathrm{sh})=4.50[1.34-15.12], \mathrm{p}=0.02)$ and showed a trend towards inverse association

220 with Sokolow-Lyon Index $(\mathrm{HR}(\mathrm{sh}) / \mathrm{mV}=0.55[0.28-1.06], \mathrm{p}=0.08)$ (cumulative incidence curves

221 in Figure 2, model results in Supplemental Table 4, cumulative incidence curves by Sokolow-

222 Lyon Index in Supplemental Figure 3).

223 Using survival analyses, composite outcome of myocarditis-related mortality or life-

224 threatening ventricular arrhythmia was inversely associated with Sokolow-Lyon Index

$225(\mathrm{HR}(\mathrm{sh}) / \mathrm{mV}=0.51[0.30-0.87], \mathrm{p}=0.01)$ and positively associated with $\mathrm{RBBB}(14 / 43$ [33\%] vs

226 14/82 [17\%]; HR(sh)=2.16 [1.05-4.47],p=0.04) and conduction disorders generally (23/79 [29\%]

227 vs 5/46 [11\%]; HR(sh)=3.05 [1.20-7.76],p=0.02) (cumulative incidence curves in Supplemental

228 Figure 4, model results in Supplemental Table 4, cumulative incidence curvesby Sokolow-Lyon 
medRxiv preprint doi: https://doi.org/10.1101/2021.02.28.21252516; this version posted March 2, 2021. The copyright holder for this preprint (which was not certified by peer review) is the author/funder, who has granted medRxiv a license to display the preprint in perpetuity.

All rights reserved. No reuse allowed without permission.

229 Index in Supplemental Figure 3). Composite outcome of myocarditis-related mortality or life-

230 threatening ventricular arrhythmia showed a trend towards association with pathological Q-

231 waves (7/19 [37\%] vs 21/106 [19.8\%]; HR(sh)=2.10 [0.90-4.89],p=0.09) and low QRS voltage

$232(3 / 6[50 \%]$ vs $25 / 119[21.0 \%] ; \mathrm{HR}(\mathrm{sh})=2.57[0.90-7.28], \mathrm{p}=0.08)$.

233 Similarly, all-cause mortality was associated with pathological Q-waves (12/19 [63\%] vs

234 18/106 [17.0\%]; HR=5.80 [2.78-12.12],p<0.001) and inversely associated with Sokolow-Lyon

235 Index $(\mathrm{HR} / \mathrm{mV}=0.59[0.35-0.98], \mathrm{p}=0.04)$ (cumulative incidence curves in Figure 2, model results

236 in Supplemental Table 4, cumulative incidence curves by Sokolow-Lyon Index in Supplemental

237 Figure 3).

238 Multivariable survival analysis was performed by adding covariates of age and sex into

239 cox proportional-hazards model and sub distribution hazards models. This analysis mirrored the

240 results of survival analyses described above (myocarditis-related mortality \& composite

241 outcome: Table 2, all-cause mortality: Supplemental Table 5; Figures 1 \& 2; Supplemental

242 Figures $2 \& \underline{3})$.

\section{Comparison to ACR}

244 The 50 patients with ACR had median (IQR) age of 51 years (43-62), 64\% (32/50) of

245 whom were male (Supplemental Table 6). Median days from transplant to ACR was 145 days

246 (IQR:26-283). 29/50 (58\%) were admitted during or as a result of ACR, with median length of

247 stay of 12 days (IQR:5-21). 2R rejection was seen in 46/50 (92\%) and 4/50 (8\%) had 3R

248 rejection. Throughout hospitalization (if applicable) or at presenting ECG, 34/50 (68\%) patients

249 experienced conduction disorders but second or third-degree heart block was not seen in any

250 patients. There was a cumulative incidence of 6/50 (12\%) supraventricular arrhythmias and 1/50 
$251(2 \%)$ life-threatening ventricular arrhythmia. None of the patients required a pacemaker and/or 252 defibrillator within 30 days after ACR diagnosis.

253 Compared to ACR, ECG at the time of ICI-myocarditis had comparable voltage and QRS

254 duration (Table 3). ICI-myocarditis had significantly more LBBB (20/125 [16.0\%] vs 0/50

$255[0 \%] ; p=0.003)$ and left anterior fascicular block (LAFB) $(24 / 125$ [19.2\%] versus 3/50

256 (6\%];p=0.02) but fewer right bundle branch block (RBBB) $(43 / 125$ [34.4\%] vs 27/50

$257[54 \%] ; \mathrm{p}=0.02)$, and right atrial abnormality (4/125 [3.2\%] vs 10/50 [20\%];p<.001). In aggregate,

258 ICI-myocarditis had more premature ventricular contractions (PVCs) (18/125 [14.4\%] vs 1/50

$259[2 \%] ; \mathrm{p}=0.02)$ but fewer repolarization abnormalities $(53 / 125[42.4 \%]$ vs 33/50 [66\%];p=0.005).

260 ACR was less severe than ICI-myocarditis in terms of 30-day all-cause mortality (0/50 [0\%] vs

$26139 / 146$ [26.7\%];p<0.001), in-hospital incidence of left ventricular ejection fraction less than 50\%

$262(4 / 28$ [14.3\%] vs 66/141 [46.8\%];p=0.001), progression to severe life-threatening ventricular

263 arrhythmias at admission or during hospital stay (1/50 [2\%] vs 22/147 [16.3\%];p=0.01), and

264 pacemaker or defibrillator placement within 30 days of the ACR or ICI-myocarditis event $(0 / 50$

$265[0 \%]$ vs 22/146 [11.1\%];p=0.004). Additionally, ACR had a lower cumulative incidence of third-

266 degree heart block (0/50 [0\%] vs 25/147 [17.0\%]; $\mathrm{p}=0.002)$ compared to ICI-myocarditis. 
medRxiv preprint doi: https://doi.org/10.1101/2021.02.28.21252516; this version posted March 2, 2021. The copyright holder for this preprint (which was not certified by peer review) is the author/funder, who has granted medRxiv a license to display the preprint in perpetuity.

\section{Discussion}

In this study, we assessed ECG features of ICI-myocarditis using a large international

272 database. We show that ICI-myocarditis manifests as clinically significant electrocardiographic

273 disturbances including high degree heart block and ventricular arrhythmias, which are strongly

274 associated with poor clinical outcomes. Compared to baseline ECG, there are also other ECG

275 manifestations, including repolarization abnormalities, decreased voltage, and increases in heart

276 rate, QRS, and QTc. Low-voltage, conduction disorders, and pathological Q-waves were

277 predictive of myocarditis-related death, life-threatening cardiac arrhythmias, and/or overall

278 mortality.

This is the first study to systematically analyze ECG in ICI-myocarditis from a large

280 number of patients with ICI-associated myocarditis with two cardiologists systematically

281 quantifying and evaluated the ECG while blinded to the clinical features for each patient.

282 Previous cohort studies had reported electrical disturbances as a major clinical feature of ICI-

283 associated myocarditis. ${ }^{6,8,22}$ Our finding that $91.8 \%$ of patients have abnormal ECG is supported

284 by Mahmoud et al's cohort of 35 patients where $89 \%$ of patients had abnormal ECG. ${ }^{6}$ In

285 addition, our finding that $42 \%$ of patients present with ST-segment or T wave abnormalities was

286 similar to the 37\% in Escudier et al.'s 30 patient cohort and 55\% in Zhang et. al's 103 patient

287 cohort. ${ }^{8,23}$ In addition, Zhang et al found $80 \%$ of patients presented in sinus rhythm with a

288 cumulative incidence of complete heart block of $16 \%$ compared to $86 \%$ and $17 \%$ respectively in

289 our cohort. $^{8}$

290 Although we hypothesized that the electrophysiological manifestations of ICI-

291 myocarditis would resemble those of ACR, given the striking pathological similarities, our

292 results show that ICI-myocarditis is both more arrhythmogenic and more lethal than ACR. Life- 
293 threatening ventricular arrhythmias, PVCs, and conduction disorders affecting the left ventricle

294 including complete heart block were more common in ICI-myocarditis but not a major feature of

295 ACR.

296 Interestingly, our study also represents the largest description of ECG findings in

297 moderate-severe ACR. While previous studies have correlated ACR with atrial arrhythmias,

298 sustained ventricular arrhythmias, PR, QRS, and QT lengthening, these changes were

299 infrequently seen in presenting ECG among our cohort. ${ }^{22,24}$ Instead, most ECG changes could be

300 explained by post-surgical changes, including sinus tachycardia, P-wave enlargement, right

301 bundle branch block, and nonspecific ST changes. ${ }^{24}$ While low voltage and pathological Q

302 waves were infrequent, they were not significantly different from the ICI-myocarditis cohort,

303 suggesting that both immune infiltrates had similar electromotive effects despite differing impact

304 on electrical conduction.

Our prognostic analysis adds to and is supportive of predictive ECG studies in general

306 myocarditis. While several studies of myocarditis due to heterogenous causes have shown

307 pathological Q-waves to be predictive of fulminant myocarditis, they did not find significant

308 association with long-term survival. ${ }^{25,26}$ While studies have shown that low-voltage lacks

309 predictive value for death in allograft rejection, it has not previously been studied in

310 myocarditis. ${ }^{10,27}$ It is interesting that while Rassi et. al found Chagas heart disease to have a $9 \%$

311 prevalence of low-voltage with a hazard ratio for mortality of 1.87 , we found a similar

312 prevalence of $8 \%$ in ICI-myocarditis but with much higher hazard ratio for mortality of

313 approximatively $4.5 .^{28}$ This may be explained by differences in acuity between these two

314 inflammatory cardiomyopathies as well as the relatively denser inflammatory infiltrates in ICI-

315 myocarditis. $^{2,29}$ 
317 intuitive markers for the extent of inflammatory infiltrate and cardiomyocyte damage. Unlike

318 low-voltage where there is a global decrease in electrical current, Q-waves represent potentials

319 from the unaffected ventricular wall opposite to an inflammatory focus that has become

320 electrically inert. The finding that these two features are strong predictors of mortality suggests

321 that suppressing the underlying inflammatory infiltrate may be a greater priority than

322 antiarrhythmic drugs or devices.

324 lymphocytes and macrophages that affect both the myocardium and the conduction system. ${ }^{2}$

325 Compared with ACR, which is primarily lymphocytic, ICI-myocarditis is characterized by both

326 lymphocyte and macrophage infiltrates with a higher CD68/CD3 (macrophages/lymphocytes)

327 ratio. ${ }^{3}$ Denser infiltrates in ICI-myocarditis are associated with increased myocyte necrosis and a

328 different molecular profile with lower macrophage expression of PD-L1 perhaps reflecting an

329 influx of the reparative M2 macrophage subpopulation. ${ }^{3}$ Importantly, macrophages have been

330 shown to electrically couple with cardiomyocytes even in the absence of disease, thereby

331 facilitating depolarization and improving AV conduction. ${ }^{30}$ It is possible that changes in

332 macrophage phenotype and density in ICI-myocarditis may mediate the high frequency of

333 conduction system blocks and ventricular ectopy seen in our cohort. Mouse models of ICI-

334 myocarditis have replicated arrhythmogenicity and lympho-histiocytic infiltration seen in

335 humans and may offer future insights into the electrical contribution of immune cells in

336 inflammatory cardiomyopathies. ${ }^{31}$ Separately, other novel forms of cancer immunotherapy also

337 demonstrate high levels of arrhythmogenicity; ventricular tachycardias and atrial fibrillation are

338 disproportionately reported in CAR-T therapy while $20 \%$ of patients receiving IL-2 therapy 
medRxiv preprint doi: https://doi.org/10.1101/2021.02.28.21252516; this version posted March 2, 2021. The copyright holder for this preprint (which was not certified by peer review) is the author/funder, who has granted medRxiv a license to display the preprint in perpetuity.

All rights reserved. No reuse allowed without permission.

339 developed arrhythmias requiring pharmacological intervention. ${ }^{32-35}$ These examples further

340 illustrate how the emerging relationship between the immune system and cardiac conduction will

341 become increasingly important in treatment of patients receiving immunotherapy and as a target

342 for arrhythmia management more broadly.

343 Although this study would not have been possible without a multicenter approach, this

344 introduced variability in data collection and interpretation. To mitigate this effect, clear criteria

345 for adjudication were provided and each submission was subjected to a bi-institutional review

346 process. Self-reporting allowed us to assemble an ICI-myocarditis cohort of this size but likely

347 selected for more clinically severe cases. To account for this in our comparison to ACR, we

348 excluded Grade 1R rejection. Nevertheless, our findings are less generalizable to low-severity

349 cases of ICI-myocarditis. The comparison to baseline ECG was limited by availability of

350 baseline ECG which likely enriched for patients with pre-existing cardiac disease thereby

351 underestimating ECG changes caused by ICI. Our analysis only interprets initial ECG and thus

352 does fully capture the predictive value of ECG changes that develop during hospitalization.

353 Although we were unable to correct for variance in treatment in the outcome analysis, we believe

354 that the composite outcome of life-threatening ventricular arrhythmia or myocarditis-related

355 death helps mitigate this by capturing early events that would have led to death if not for

356 aggressive therapy.

357 Conclusions

On ECG, ICI-myocarditis manifests as diffuse alteration of the cardiac conduction system

359 represented by conduction blocks, decrease in QRS voltage, and appearance of cardiomyocyte

360 death with pathological Q-waves. These features predict severe life-threatening ventricular

361 arrhythmias and death. Clinicians should focus on identifying these ECG changes as part of 
medRxiv preprint doi: https://doi.org/10.1101/2021.02.28.21252516; this version posted March 2, 2021. The copyright holder for this preprint (which was not certified by peer review) is the author/funder, who has granted medRxiv a license to display the preprint in perpetuity. All rights reserved. No reuse allowed without permission.

362 multimodal diagnostic workup for ICI-myocarditis. Patients with these features are at higher risk

363 for adverse outcomes and may benefit from more aggressive treatment and monitoring strategies.

\section{Acknowledgments}

366 We would like to thank all the collaborators who have participated in this multicenter database

367 (Supplemental Table 1). This study was supported by the following grants: UL1 TR000445 from

368 NCATS/NIH. 
medRxiv preprint doi: https://doi.org/10.1101/2021.02.28.21252516; this version posted March 2, 2021. The copyright holder for this preprint (which was not certified by peer review) is the author/funder, who has granted medRxiv a license to display the preprint in perpetuity.

\section{References (38 / 50-75 citations)}

370 1. Haslam A, Prasad V. Estimation of the Percentage of US Patients With Cancer Who Are Eligible for and Respond to Checkpoint Inhibitor Immunotherapy Drugs. JAMA network open. 2019;2(5):e192535-e192535. doi:10.1001/jamanetworkopen.2019.2535

2. Johnson DB, Balko JM, Compton ML, et al. Fulminant Myocarditis with Combination Immune Checkpoint Blockade. The New England journal of medicine. 2016;375(18):1749-1755. doi:10.1056/NEJMoa1609214

3. Champion SN, Stone JR. Immune checkpoint inhibitor associated myocarditis occurs in both high-grade and low-grade forms. Modern pathology $\square$ : an official journal of the United States and Canadian Academy of Pathology, Inc. 2020;33(1):99-108. doi:10.1038/s41379-019-0363-0

4. Salem J-E, Allenbach Y, Vozy A, et al. Abatacept for Severe Immune Checkpoint Inhibitor-Associated Myocarditis. The New England journal of medicine. 2019;380(24):2377-2379. doi:10.1056/NEJMc1901677

5. Salem J-E, Manouchehri A, Moey M, et al. Cardiovascular toxicities associated with immune checkpoint inhibitors: an observational, retrospective, pharmacovigilance study. The Lancet Oncology. 2018;19(12):1579-1589. doi:10.1016/S1470-2045(18)30608-9

6. Mahmood SS, Fradley MG, Cohen J V, et al. Myocarditis in Patients Treated With Immune Checkpoint Inhibitors. Journal of the American College of Cardiology. 2018;71(16):1755-1764. doi:10.1016/j.jacc.2018.02.037

7. Norwood TG, Westbrook BC, Johnson DB, et al. Smoldering myocarditis following immune checkpoint blockade. Journal for immunotherapy of cancer. 2017;5(1):91. doi:10.1186/s40425-017-0296-4

8. Zhang L, Awadalla M, Mahmood SS, et al. Cardiovascular magnetic resonance in immune checkpoint inhibitor-associated myocarditis. European heart journal. February 2020. doi:10.1093/eurheartj/ehaa051

9. Bonaca MP, Olenchock BA, Salem J-E, et al. Myocarditis in the Setting of Cancer Therapeutics: Proposed Case Definitions for Emerging Clinical Syndromes in CardioOncology. Circulation. 2019;140(2):80-91. doi:10.1161/CIRCULATIONAHA.118.034497

10. Locke TJ, Karnik R, McGregor CG, Bexton RS. The value of the electrocardiogram in the diagnosis of acute rejection after orthotopic heart transplantation. Transplant international $\square$ : official journal of the European Society for Organ Transplantation. 1989;2(3):143-146. doi:10.1007/bf02414601

11. Kowalski O, Zakliczyński M, Lenarczyk R, et al. Electrophysiologic parameters suggesting significant acute cellular rejection of the transplanted heart. Annals of transplantation. 2006;11(1):35-39.

12. Geraud A, Gougis P, Vozy A, et al. Clinical Pharmacology and Interplay of Immune Checkpoint Agents: A Yin-Yang Balance. Annual review of pharmacology and toxicology. September 2020. doi:10.1146/annurev-pharmtox-022820-093805

13. Zhang L, Zlotoff DA, Awadalla M, et al. Major Adverse Cardiovascular Events and the Timing and Dose of Corticosteroids in Immune Checkpoint Inhibitor-Associated Myocarditis. Circulation. 2020;141(24):2031-2034. doi:10.1161/CIRCULATIONAHA.119.044703

14. Jain V, Mohebtash M, Rodrigo ME, Ruiz G, Atkins MB, Barac A. Autoimmune 
medRxiv preprint doi: https://doi.org/10.1101/2021.02.28.21252516; this version posted March 2, 2021. The copyright holder for this preprint (which was not certified by peer review) is the author/funder, who has granted medRxiv a license to display the preprint in perpetuity. All rights reserved. No reuse allowed without permission.

Myocarditis Caused by Immune Checkpoint Inhibitors Treated With Antithymocyte Globulin. Journal of immunotherapy (Hagerstown, Md $\square$ : 1997). 2018;41(7):332-335. doi:10.1097/CJI.0000000000000239

15. Tay RY, Blackley E, McLean C, et al. Successful use of equine anti-thymocyte globulin (ATGAM) for fulminant myocarditis secondary to nivolumab therapy. British journal of cancer. 2017;117(7):921-924. doi:10.1038/bjc.2017.253

16. Bonaros N, Dunkler D, Kocher A, et al. Ten-year follow-up of a prospective, randomized trial of BT563/bb10 versus anti-thymocyte globulin as induction therapy after heart transplantation. The Journal of heart and lung transplantation $\square$ : the official publication of the International Society for Heart Transplantation. 2006;25(9):1154-1163. doi:10.1016/j.healun.2006.03.024

17. Ruan V, Czer LSC, Awad M, et al. Use of Anti-Thymocyte Globulin for Induction Therapy in Cardiac Transplantation: A Review. Transplantation proceedings. 2017;49(2):253-259. doi:10.1016/j.transproceed.2016.11.034

18. Caforio ALP, Pankuweit S, Arbustini E, et al. Current state of knowledge on aetiology, diagnosis, management, and therapy of myocarditis: a position statement of the European Society of Cardiology Working Group on Myocardial and Pericardial Diseases. European heart journal. 2013;34(33):2636-2648, 2648a-2648d. doi:10.1093/eurheartj/eht210

19. Harris PA, Taylor R, Thielke R, Payne J, Gonzalez N, Conde JG. Research electronic data capture (REDCap)--a metadata-driven methodology and workflow process for providing translational research informatics support. Journal of biomedical informatics. 2009;42(2):377-381. doi:10.1016/j.jbi.2008.08.010

20. Harris PA, Taylor R, Minor BL, et al. The REDCap consortium: Building an international community of software platform partners. Journal of biomedical informatics. 2019;95:103208. doi:10.1016/j.jbi.2019.103208

21. Stewart S, Winters GL, Fishbein MC, et al. Revision of the 1990 working formulation for the standardization of nomenclature in the diagnosis of heart rejection. The Journal of heart and lung transplantation $\square:$ the official publication of the International Society for Heart Transplantation. 2005;24(11):1710-1720. doi:10.1016/j.healun.2005.03.019

22. Hickey KT, Sciacca RR, Chen B, et al. Electrocardiographic Correlates of Acute Allograft Rejection Among Heart Transplant Recipients. American journal of critical care $\square$ : an official publication, American Association of Critical-Care Nurses. 2018;27(2):145-150. doi:10.4037/ajcc2018862

23. Escudier M, Cautela J, Malissen N, et al. Clinical Features, Management, and Outcomes of Immune Checkpoint Inhibitor-Related Cardiotoxicity. Circulation. 2017;136(21):20852087. doi:10.1161/CIRCULATIONAHA.117.030571

24. Sandhu JS, Curtiss EI, Follansbee WP, Zerbe TR, Kormos RL. The scalar electrocardiogram of the orthotopic heart transplant recipient. American heart journal. 1990;119(4):917-923. doi:10.1016/s0002-8703(05)80332-1

25. Nakashima H, Katayama T, Ishizaki M, Takeno M, Honda Y, Yano K. Q wave and non-Q wave myocarditis with special reference to clinical significance. Japanese heart journal. 1998;39(6):763-774. doi:10.1536/ihj.39.763

26. Morgera T, Di Lenarda A, Dreas L, et al. Electrocardiography of myocarditis revisited: clinical and prognostic significance of electrocardiographic changes. American heart journal. 1992;124(2):455-467. doi:10.1016/0002-8703(92)90613-Z

27. Keren A, Gillis AM, Freedman RA, et al. Heart transplant rejection monitored by signal- 
medRxiv preprint doi: https://doi.org/10.1101/2021.02.28.21252516; this version posted March 2, 2021. The copyright holder for this preprint (which was not certified by peer review) is the author/funder, who has granted medRxiv a license to display the preprint in perpetuity.

All rights reserved. No reuse allowed without permission.

averaged electrocardiography in patients receiving cyclosporine. Circulation. 1984;70(3 Pt 2):I124-9.

28. Rassi AJ, Rassi A, Little WC, et al. Development and validation of a risk score for predicting death in Chagas' heart disease. The New England journal of medicine. 2006;355(8):799-808. doi:10.1056/NEJMoa053241

29. Pereira Barretto AC, Mady C, Arteaga-Fernandez E, et al. Right ventricular endomyocardial biopsy in chronic Chagas' disease. American heart journal. 1986;111(2):307-312. doi:10.1016/0002-8703(86)90144-4

30. Hulsmans M, Clauss S, Xiao L, et al. Macrophages Facilitate Electrical Conduction in the Heart. Cell. 2017;169(3):510-522.e20. doi:10.1016/j.cell.2017.03.050

31. Wei SC, Meijers WC, Axelrod ML, et al. A genetic mouse model recapitulates immune checkpoint inhibitor-associated myocarditis and supports a mechanism-based therapeutic intervention. Cancer discovery. November 2020. doi:10.1158/2159-8290.CD-20-0856

32. Natali LC, Maddukuri P, Lucariello R, et al. Significant arrhythmias associated with Interleukin-2 therapy. Journal of Clinical Oncology. 2005;23(16_suppl):2588. doi:10.1200/jco.2005.23.16_suppl.2588

33. Salem J-E, Ederhy S, Lebrun-Vignes B, Moslehi JJ. Cardiac Events Associated With Chimeric Antigen Receptor T-Cells (CAR-T): A VigiBase Perspective. Journal of the American College of Cardiology. 2020;75(19):2521-2523. doi:10.1016/j.jacc.2020.02.070

34. Lefebvre B, Kang Y, Smith AM, Frey N V, Carver JR, Scherrer-Crosbie M. Cardiovascular Effects of CAR T Cell Therapy: A Retrospective Study. JACC CardioOncology. 2020;2(2):193-203. doi:10.1016/j.jaccao.2020.04.012

35. Alvi RM, Frigault MJ, Fradley MG, et al. Cardiovascular Events Among Adults Treated With Chimeric Antigen Receptor T-Cells (CAR-T). Journal of the American College of Cardiology. 2019;74(25):3099-3108. doi:10.1016/j.jacc.2019.10.038

36. Surawicz B, Childers R, Deal BJ, et al. AHA/ACCF/HRS recommendations for the standardization and interpretation of the electrocardiogram: part III: intraventricular conduction disturbances: a scientific statement from the American Heart Association Electrocardiography and Arrhythmias Committee. Journal of the American College of Cardiology. 2009;53(11):976-981. doi:10.1016/j.jacc.2008.12.013

37. Thygesen K, Alpert JS, Jaffe AS, et al. Fourth Universal Definition of Myocardial Infarction (2018). Journal of the American College of Cardiology. 2018;72(18):22312264. doi:10.1016/j.jacc.2018.08.1038

38. Hancock EW, Deal BJ, Mirvis DM, et al. AHA/ACCF/HRS recommendations for the standardization and interpretation of the electrocardiogram: part V: electrocardiogram changes associated with cardiac chamber hypertrophy: a scientific statement from the American Heart Association Electrocardiograph. Journal of the American College of Cardiology. 2009;53(11):992-1002. doi:10.1016/j.jacc.2008.12.015 
Table 1. ICI-myocarditis cases characteristics and outcomes

\begin{tabular}{|c|c|}
\hline & \multirow{3}{*}{$\begin{array}{r}\text { Total } \\
\text { Med (IQR) N; n/N }(\%)\end{array}$} \\
\hline & \\
\hline & \\
\hline & $67(58-77)$ \\
\hline Age & $\mathrm{N}=147$ \\
\hline Female & $55 / 147(37.4 \%)$ \\
\hline Bodv Mass Index & $25.3(21.4-28.8)$ \\
\hline Boay ivass maex & $\mathrm{N}=138$ \\
\hline Hyperlipidemia & $49 / 138(35.5 \%)$ \\
\hline Diabetes & $25 / 138(18.1 \%)$ \\
\hline Hypertension & $77 / 140(55.0 \%)$ \\
\hline Prior Tobacco User & $69 / 137(50.4 \%)$ \\
\hline Pre-existing Stroke & $5 / 138(3.6 \%)$ \\
\hline Pre-existing Peripheral Vascular Disease & $11 / 137(8.0 \%)$ \\
\hline Pre-existing Coronary Artery Disease & $27 / 139(19.4 \%)$ \\
\hline Pre-existing Heart Failure & $16 / 138(11.6 \%)$ \\
\hline $\begin{array}{l}1 \text { or More Traditional Cardiovascular Risk Factors (defined as HLD or } \\
\text { DM2 or HTN or Tobacco use) }\end{array}$ & $115 / 140(82.1 \%)$ \\
\hline Prior History of Cardiac Disease (defined as CAD or CHF) & $34 / 137(24.8 \%)$ \\
\hline $\begin{array}{l}\text { Prior History of Cardiovascular Disease (PVD, CVA, CAD, CHF or } \\
\text { HTN) }\end{array}$ & $89 / 138(64.5 \%)$ \\
\hline Index ICI Therapy Category & \\
\hline - Anti CTLA-4 \& PD1/PDL1 Combination Therapy & $27 / 147(18.4 \%)$ \\
\hline - Anti CTLA-4 Monotherapy & $41 / 147(27.9 \%)$ \\
\hline - $\quad$ Anti PD1/PDL1 Monotherapy & $79 / 147(53.7 \%)$ \\
\hline Days from First ICI Dose to Hospital Admission & $\begin{array}{r}38(21-83) \\
\mathrm{N}=139\end{array}$ \\
\hline Days from Last ICI Dose to Hospital Admission & $\begin{array}{r}15(9-22) \\
N=139\end{array}$ \\
\hline Number of Doses ICI Received & $2(1-4) \mathrm{N}=140$ \\
\hline Cancer Type & \\
\hline - Bladder Cancer & $4 / 147(2.7 \%)$ \\
\hline - Breast Cancer & $1 / 147(0.7 \%)$ \\
\hline - Kidney Cancer & $16 / 147(10.9 \%)$ \\
\hline - Leukemia & $2 / 147(1.4 \%)$ \\
\hline - Lung Cancer & $52 / 147(35.4 \%)$ \\
\hline - $\quad$ Non-Hodgkin Lymphoma & $1 / 147(0.7 \%)$ \\
\hline - Prostate Cancer & $2 / 147(1.4 \%)$ \\
\hline - Melanoma & $40 / 147(27.2 \%)$ \\
\hline - $\quad$ Thymic Cancer (Non-Thymoma) & $2 / 147(1.4 \%)$ \\
\hline - Esophageal Cancer & $4 / 147(2.7 \%)$ \\
\hline
\end{tabular}




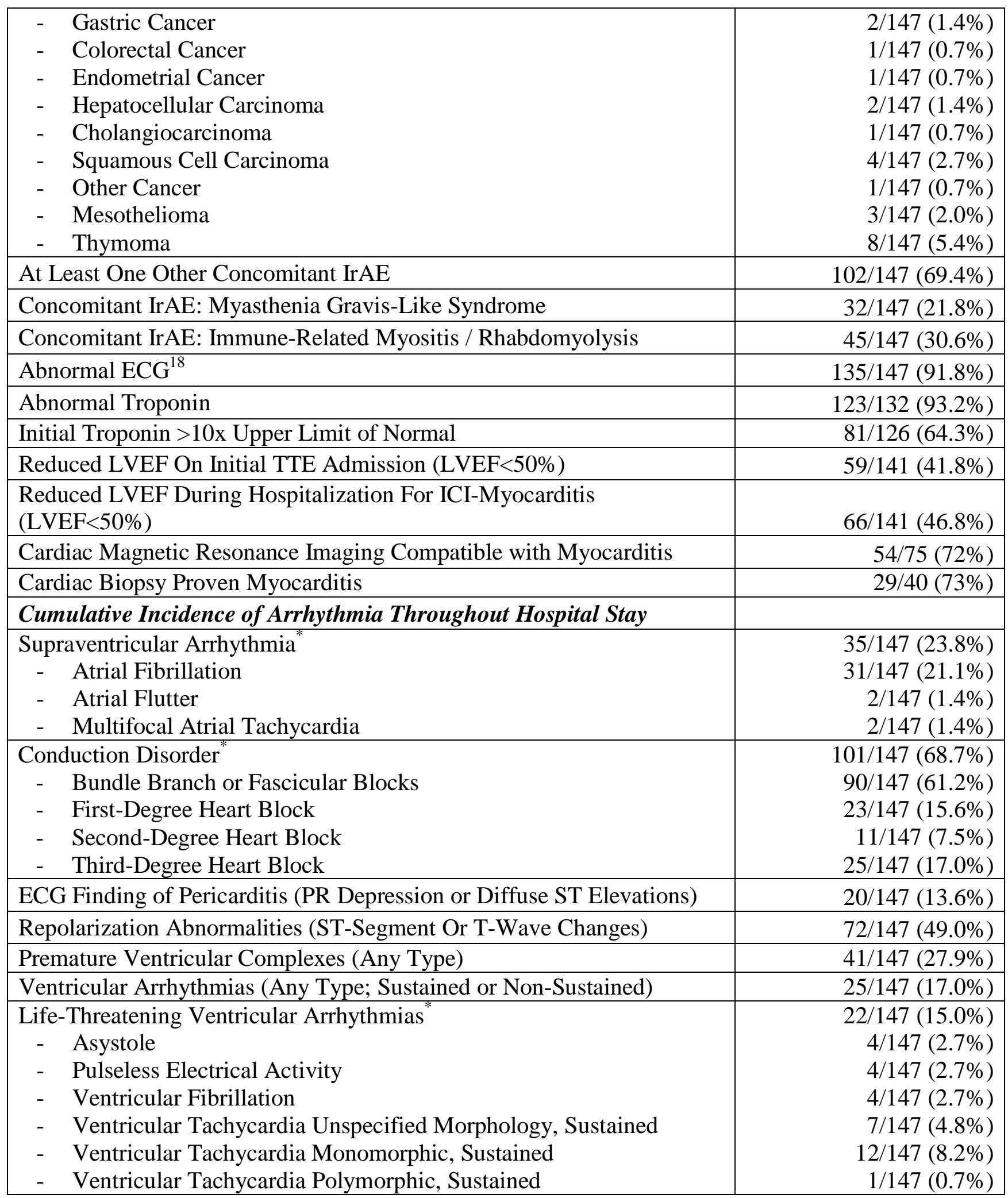




\begin{tabular}{|c|c|}
\hline - $\quad$ Ventricular Tachycardia Torsade De Pointes, Sustained & $2 / 147(1.4 \%)$ \\
\hline $\begin{array}{l}\text { Third-Degree Heart Block and/or Life-Threatening Ventricular } \\
\text { Arrhythmia }\end{array}$ & $36 / 147(24.5 \%)$ \\
\hline Third-Degree Heart Block and Life-Threatening Ventricular Arrhythmia & $11 / 147(7.5 \%)$ \\
\hline Outcome & \\
\hline Placement of a Pacemaker and/or Defibrillator Within 30 days & $22 / 146(15.1 \%)$ \\
\hline Pacemaker Without Defibrillator Within 30 days & $21 / 146(14.4 \%)$ \\
\hline Length of Stay (In Days) & $11(7-24) \mathrm{N}=98$ \\
\hline In-Hospital Mortality & $42 / 147(28.6 \%)$ \\
\hline 30-Day All-Cause Mortality & $39 / 146(26.7 \%)$ \\
\hline $\begin{array}{l}\text { 30-Day Myocarditis-Related Mortality or Life-Threatening Ventricular } \\
\text { Arrhythmia }\end{array}$ & $37 / 146(25.3 \%)$ \\
\hline $\begin{array}{l}\text { Diagnostic Certainty } \\
\text { - } \\
\text { - } \\
\text { - } \\
\text { Pefinite Myocable Myocarditis } \\
\text { Possible Myocarditis }\end{array}$ & $\begin{array}{l}81 / 143(56.6 \%) \\
27 / 143(18.9 \%) \\
35 / 143(24.5 \%)\end{array}$ \\
\hline $\begin{array}{l}\text { Cause of Death }{ }^{\dagger} \text { (Of } 39 \text { Patients With 30d All-Cause Mortality) } \\
\text { Myocarditis } \\
\text { Cancer Progression } \\
\text { Immune Related Adverse Event Other Than Cardiotoxicity } \\
\text { - Non-Cardiac Myotoxicities Including Myasthenia Gravis-Like } \\
\quad \text { Syndrome Associated with Diaphragmatic Failure } \\
\text { - Thrombocytopenia, Immune Related } \\
\text { Sepsis } \\
\text { Thromboembolic Event } \\
\text { Hemorrhage } \\
\text { Respiratory Failure (Other Than Diaphragmatic Failure) } \\
\text { - Pulmonary Infection } \\
\text { - Acute Respiratory Distress Syndrome } \\
\text { Ischemic Stroke } \\
\text { Unknown }\end{array}$ & $\begin{array}{r}24 / 39(61.5 \%) \\
6 / 39(15.4 \%) \\
7 / 39(17.9 \%) \\
6 / 7(85.7 \%) \\
\\
1 / 7(14.3 \%) \\
6 / 39(15.4 \%) \\
2 / 39(5.1 \%) \\
3 / 39(7.7 \%) \\
3 / 39(7.7 \%) \\
2 / 3(66.7 \%) \\
2 / 3(66.7 \%) \\
1 / 39(2.6 \%) \\
1 / 39(2.6 \%)\end{array}$ \\
\hline
\end{tabular}

Abbreviations: $C A D$ : coronary artery diseases; $C H F$ : congestive heart failure; $C T L A-4$ : Cytotoxic T-lymphocyte-associated protein 4; CVA: Cerebrovascular accident; HTN: Hypertension; ICI: Immune checkpoint inhibitor; IrAE: Immune Related Adverse Event; LVEF: Left ventricular ejection fraction; PD1: Programmed cell death protein 1; PD-L1: echocardiogram 


\begin{tabular}{|c|c|c|c|c|c|}
\hline & $\begin{array}{r}\text { ICI-Myocarditis, } \\
\text { Presenting ECG }\end{array}$ & $\begin{array}{r}\text { ICI-Myocarditis, } \\
\text { Baseline ECG }\end{array}$ & & $\begin{array}{r}\text { Subdistribution Hazards } \\
\text { Model For 30d Myocarditis- } \\
\text { Related Mortality Adjusting } \\
\text { for Age and Sex }\end{array}$ & $\begin{array}{r}\text { Subdistribution Hazards } \\
\text { Model For 30d Composite } \\
\text { Outcome Adjusting for Age } \\
\text { and Sex }\end{array}$ \\
\hline & $\begin{array}{r}\operatorname{Med}(\mathbf{I Q R}) \mathbf{N} ; \\
\mathbf{n} / \mathbf{N}(\%)\end{array}$ & $\begin{array}{r}\text { Med (IQR) N; } \\
\mathbf{n} / \mathbf{N}(\%)\end{array}$ & $\begin{array}{r}\text { p-value } \\
\text { (paired T- } \\
\text { test) }\end{array}$ & HR(sh) $[95 \%$ CI], p-value* & HR(sh) $[95 \%$ CI $]$, p-value* \\
\hline Heart Rate (bpm) & $\begin{array}{r}93.9[72.6-114.7] \\
\mathrm{N}=52 \\
\end{array}$ & $\begin{array}{r}80.4[68.1-94.8] \\
\mathrm{N}=52\end{array}$ & 0.009 & $1.01[0.99-1.03], \mathrm{p}=.52 \mathrm{~N}=125$ & $1.00[0.99-1.02], p=.60 \mathrm{~N}=125$ \\
\hline PR Length (ms) & $\begin{array}{r}162.8[136.0- \\
186.0] \mathrm{N}=42 \\
\end{array}$ & $\begin{array}{r}154.1[136.0- \\
187.6] \mathrm{N}=46 \\
\end{array}$ & 0.10 & $1.00[0.99-1.02], p=.90 \mathrm{~N}=107$ & $1[0.99-1.01], p=.62 \mathrm{~N}=107$ \\
\hline QTcF Length (ms) & $\begin{array}{r}441.8[414.9- \\
462.6] \mathrm{N}=49\end{array}$ & $\begin{array}{r}421.0[399.2- \\
440.4] \mathrm{N}=51 \\
\end{array}$ & 0.03 & $1.00[0.99-1.01], p=.59 \mathrm{~N}=122$ & $1.00[1.00-1.01], p=.42 \mathrm{~N}=122$ \\
\hline QRS Length (ms) & $\begin{array}{r}95.3[85.7-118.2] \\
\mathrm{N}=52 \\
\end{array}$ & $\begin{array}{r}93.2[82.7-102.5] \\
\mathrm{N}=52\end{array}$ & 0.02 & $1.01[0.99-1.02], p=.57 \mathrm{~N}=125$ & $1.01[1-1.03], p=.03 \mathrm{~N}=125$ \\
\hline \multirow[t]{2}{*}{ Sokolow-Lyon Index (mV) } & $\begin{array}{r}1.39[0.85-2.03] \\
\mathrm{N}=52 \\
\end{array}$ & $\begin{array}{r}1.69[1.28-2.26] \\
\mathrm{N}=52\end{array}$ & 0.006 & $0.54[0.30-0.97], p=.04 \mathrm{~N}=124$ & $0.50[0.30-0.85], \mathrm{p}=.01 \mathrm{~N}=124$ \\
\hline & & & $\begin{array}{r}\text { p-value } \\
\text { (McNemar's } \\
\text { test) }\end{array}$ & & \\
\hline CONDUCTION DISORDERS $^{\dagger}$ & $35 / 52(67 \%)$ & $23 / 52(44 \%)$ & 0.01 & $1.91[0.71-5.14], p=.20 \mathrm{~N}=125$ & $3.27[1.29-8.34], p=.01 \mathrm{~N}=125$ \\
\hline $\begin{array}{l}\text { Bundle Branch Block, Left } \\
\text { Bundle }\end{array}$ & $10 / 52(19 \%)$ & $3 / 52(6 \%)$ & 0.05 & $0.85[0.26-2.79], p=.79 \mathrm{~N}=125$ & $1.49[0.62-3.61], \mathrm{p}=.37 \mathrm{~N}=125$ \\
\hline $\begin{array}{ll}\text { - } & \text { Bundle Branch Block, Right } \\
\text { Bundle }\end{array}$ & $14 / 52(27 \%)$ & $9 / 52(17 \%)$ & 0.18 & $1.63[0.69-3.85], p=.27 \mathrm{~N}=125$ & 2.22 [1.06-4.67], $\mathrm{p}=.04 \mathrm{~N}=125$ \\
\hline $\begin{array}{l}\text { - Fascicular Block, Left } \\
\text { Anterior }\end{array}$ & $10 / 52(19 \%)$ & $5 / 52(10 \%)$ & 0.23 & $1.58[0.57-4.41], p=.38 \mathrm{~N}=125$ & $1.81[0.82-3.97], p=.14 \mathrm{~N}=125$ \\
\hline $\begin{array}{ll}\text { - } & \text { Fascicular Block, Left } \\
& \text { Posterior } \\
\end{array}$ & $6 / 52(12 \%)$ & $2 / 52(4 \%)$ & 0.22 & $1.40[0.47-4.14], p=.54 \mathrm{~N}=125$ & $1.56[0.52-4.62], p=.43 \mathrm{~N}=125$ \\
\hline
\end{tabular}

Only arrhythmia subgroups with at least $\mathrm{n}>2$ in ICI-myocarditis presenting ECG are shown

$\dagger \quad$ When multiple eligible ECG were available, ECG without complete heart block or supraventricular arrhythmias were preferentially selected for this analysis focusing on PR, QRS and QTc measurements. Please see Table 1 for cumulative incidence of arrhythmias in ICI-myocarditis. 


\begin{tabular}{|c|c|c|c|c|c|}
\hline - $\quad$ Heart Block, First Degree & $9 / 52(17 \%)$ & $7 / 52(13 \%)$ & 0.72 & $1.78[0.57-5.58], p=.32 \mathrm{~N}=125$ & $2.14[0.83-5.53], p=.12 \mathrm{~N}=125$ \\
\hline ECG Findings of Pericarditis & $4 / 52(8 \%)$ & $1 / 52(2 \%)$ & 0.25 & $0.58[0.14-2.40], p=.46 \mathrm{~N}=125$ & $0.98[0.34-2.82], p=.97 \mathrm{~N}=125$ \\
\hline $\begin{array}{l}\text { ST Segment Elevation, } \\
\text { Diffuse }\end{array}$ & $3 / 52(6 \%)$ & $1 / 52(2 \%)$ & 0.62 & $0.63[0.15-2.61], p=.52 \mathrm{~N}=125$ & $1.05[0.36-3.05], p=.93 \mathrm{~N}=125$ \\
\hline $\begin{array}{l}\text { PREMATURE VENTRICULAR } \\
\text { COMPLEX (ALL TYPES) }\end{array}$ & $9 / 52(17 \%)$ & $3 / 52(6 \%)$ & 0.08 & $1.36[0.43-4.32], p=.61 \mathrm{~N}=125$ & $1.95[0.74-5.10], p=.18 \mathrm{~N}=125$ \\
\hline $\begin{array}{ll}- & \text { Premature Ventricular } \\
\text { Complex }\end{array}$ & $9 / 52(17 \%)$ & $3 / 52(6 \%)$ & 0.08 & $0.96[0.27-3.38], p=.95 \mathrm{~N}=125$ & $1.51[0.56-4.07], p=.42 \mathrm{~N}=125$ \\
\hline SINUS MECHANISM & $42 / 52(81 \%)$ & $46 / 52(88 \%)$ & 0.29 & $0.58[0.21-1.59], p=.29 \mathrm{~N}=125$ & $0.70[0.29-1.70], p=.43 \mathrm{~N}=125$ \\
\hline - $\quad$ Normal Sinus Rhythm & $17 / 52(33 \%)$ & $31 / 52(60 \%)$ & 0.002 & $0.43[0.16-1.16], p=.09 \mathrm{~N}=125$ & $0.61[0.28-1.32], p=.21 \mathrm{~N}=125$ \\
\hline - $\quad$ Sinus Tachycardia & $25 / 52(48 \%)$ & $15 / 52(29 \%)$ & 0.02 & $1.48[0.6-3.65], p=.39 \mathrm{~N}=125$ & $1.28[0.61-2.68], \mathrm{p}=.52 \mathrm{~N}=125$ \\
\hline $\begin{array}{l}\text { REPOLARIZATION } \\
\text { ABNORMALITIES }\end{array}$ & $27 / 52(52 \%)$ & $13 / 52(25 \%)$ & 0.008 & $1.57[0.64-3.89], p=.33 \mathrm{~N}=125$ & $1.48[0.68-3.24], \mathrm{p}=.33 \mathrm{~N}=125$ \\
\hline $\begin{array}{l}\text { ST Segment Depression, } \\
\text { Diffuse }\end{array}$ & $5 / 52(10 \%)$ & $1 / 52(2 \%)$ & 0.22 & $0.66[0.09-4.73], p=.68 \mathrm{~N}=125$ & $0.47[0.07-3.27], p=.44 \mathrm{~N}=125$ \\
\hline $\begin{array}{l}\text { ST Segment Depression, } \\
\text { Regional }\end{array}$ & $4 / 52(8 \%)$ & $0 / 52(0 \%)$ & NA & $1.04[0.13-8.56], p=.97 \mathrm{~N}=125$ & $1.48[0.35-6.32], p=.59 \mathrm{~N}=125$ \\
\hline - $\quad$ T Wave Inversions & $21 / 52(40 \%)$ & $12 / 52(23 \%)$ & 0.07 & $1.98[0.81-4.82], p=.13 \mathrm{~N}=125$ & $1.42[0.63-3.24], p=.40 \mathrm{~N}=125$ \\
\hline $\begin{array}{l}\text { SUPRAVENTRICULAR } \\
\text { ARRHYTHMIA }^{\dagger}\end{array}$ & $7 / 52(13 \%)$ & $6 / 52(12 \%)$ & 1.00 & $2.84[0.99-8.16], \mathrm{p}=.052 \mathrm{~N}=125$ & $2.39[1.01-5.65], p=.047 \mathrm{~N}=125$ \\
\hline$-\quad$ Atrial Fibrillation $^{\dagger}$ & $6 / 52(12 \%)$ & $5 / 52(10 \%)$ & 1.00 & $2.19[0.67-7.24], p=.20 \mathrm{~N}=125$ & $2.11[0.77-5.76], p=.14 \mathrm{~N}=125$ \\
\hline \multicolumn{6}{|l|}{ UNCATEGORIZED } \\
\hline Premature Atrial Complex & $5 / 52(10 \%)$ & $3 / 52(6 \%)$ & 0.68 & $2.19[0.57-8.45], p=.26 \mathrm{~N}=125$ & $1.63[0.49-5.43], p=.42 \mathrm{~N}=125$ \\
\hline Left Ventricular Hypertrophy & $12 / 52(23 \%)$ & $16 / 52(31 \%)$ & 0.34 & $0.71[0.21-2.43], p=.58 \mathrm{~N}=125$ & 0.51 [0.16-1.63], $\mathrm{p}=.25 \mathrm{~N}=125$ \\
\hline Low QRS Voltage & $4 / 52(8 \%)$ & $1 / 52(2 \%)$ & 0.37 & $\begin{array}{r}6.05[2.10-17.39], \mathrm{p}<.001 \\
\mathrm{~N}=125\end{array}$ & $2.70[0.97-7.49], p=.06 \mathrm{~N}=125$ \\
\hline $\begin{array}{l}\text { P Wave Abnormality Suggestive of } \\
\text { Left Atrial Enlargement }\end{array}$ & $11 / 52(21 \%)$ & $9 / 52(17 \%)$ & 0.75 & $1.40[0.53-3.71], p=.49 \mathrm{~N}=125$ & $1.09[0.46-2.59], p=.85 \mathrm{~N}=125$ \\
\hline Q Waves, Pathological & $8 / 52(15 \%)$ & $4 / 52(8 \%)$ & 0.22 & $3.40[1.38-8.33], p=.008 \mathrm{~N}=125$ & $2.20[0.95-5.12], p=.07 \mathrm{~N}=125$ \\
\hline
\end{tabular}


medRxiv preprint doi: https://doi.org/10.1101/2021.02.28.21252516; this version posted March 2, 2021. The copyright holder for this preprint (which was not certified by peer review) is the author/funder, who has granted medRxiv a license to display the preprint in perpetuity.

All rights reserved. No reuse allowed without permission.

510 Table 3: Comparison on ECG findings in ICI-myocarditis to acute cellular rejection at

\section{1 presentation}

\begin{tabular}{|c|c|c|c|}
\hline & $\begin{array}{l}\text { ICI-Myocarditis, Presenting } \\
\text { ECG } \\
\text { N=125 }\end{array}$ & $\begin{array}{l}\text { Acute Cellular Rejection } \\
\text { 2R/3R Presenting ECG } \\
\mathrm{N}=50\end{array}$ & \\
\hline & & & $\begin{array}{l}\text { p-value } \\
\text { (Wilcoxon } \\
\text { test) }\end{array}$ \\
\hline Heart Rate (bpm) & $87.6[71.3-104.6] \mathrm{N}=125$ & $88.8[80.4-110.2] \mathrm{N}=50$ & 0.20 \\
\hline PR Interval Length (ms) & $161.3[145.7-180.6] \mathrm{N}=107$ & $153.2[136.5-166.1] \mathrm{N}=48$ & 0.01 \\
\hline QTcF Length (ms) & $432.5[405.4-462.1] \mathrm{N}=122$ & $434.1[393.5-460.1] \mathrm{N}=49$ & 0.59 \\
\hline QRS Length (ms) & $95.0[85.3-122.3] \mathrm{N}=125$ & $92.8[85.5-103.2] \mathrm{N}=49$ & 0.15 \\
\hline Sokolow-Lyon Index & $1.240[0.700-1.889] \mathrm{N}=124$ & $1.421[0.889-1.845] \mathrm{N}=50$ & 0.40 \\
\hline & & & $\begin{array}{r}\text { p-value (Chi- } \\
\text { square test) }\end{array}$ \\
\hline CONDUCTION DISORDERS & $79 / 125(63 \%) \mathrm{N}=125$ & $34 / 50(68 \%) \mathrm{N}=50$ & 0.55 \\
\hline $\begin{array}{l}\text { - Bundle Branch Block, Left } \\
\text { Bundle }\end{array}$ & $20 / 125(16 \%) \mathrm{N}=125$ & $0 / 50(0 \%) \mathrm{N}=50$ & 0.003 \\
\hline $\begin{array}{l}\text { Bundle Branch Block, } \\
\text { Nonspecific }\end{array}$ & $2 / 125(2 \%) \mathrm{N}=125$ & $2 / 50(4 \%) \mathrm{N}=50$ & 0.34 \\
\hline $\begin{array}{l}\text { - } \quad \text { Bundle Branch Block, Right } \\
\text { Bundle }\end{array}$ & $43 / 125(34 \%) \mathrm{N}=125$ & $27 / 50(54 \%) \mathrm{N}=50$ & 0.02 \\
\hline - $\quad$ Escape Rhythm, Ventricular & $1 / 125(1 \%) \mathrm{N}=125$ & $0 / 50(0 \%) \mathrm{N}=50$ & 0.53 \\
\hline - $\quad$ Fascicular Block, Left Anterior & $24 / 125(19 \%) \mathrm{N}=125$ & $3 / 50(6 \%) \mathrm{N}=50$ & 0.03 \\
\hline - $\quad$ Fascicular Block, Left Posterior & $13 / 125(10 \%) \mathrm{N}=125$ & $4 / 50(8 \%) \mathrm{N}=50$ & 0.63 \\
\hline - $\quad$ Heart Block, First Degree & $18 / 125(14 \%) \mathrm{N}=125$ & $5 / 50(10 \%) \mathrm{N}=50$ & 0.44 \\
\hline - $\quad$ Heart Block, Third Degree* & $5 / 125(4 \%) \mathrm{N}=125$ & $0 / 50(0 \%) \mathrm{N}=50$ & 0.15 \\
\hline
\end{tabular}

* When multiple eligible ECG were available, ECG without complete heart block or supraventricular arrhythmias were preferentially selected for this analysis focusing on PR, QRS and QTc measurements. Please see Table 1 for cumulative incidence of arrhythmias in ICI-myocarditis and Supplemental-Table-3 for cumulative incidence of arrhythmias in ACR. 
medRxiv preprint doi: https://doi.org/10.1101/2021.02.28.21252516; this version posted March 2, 2021. The copyright holder for this preprint (which was not certified by peer review) is the author/funder, who has granted medRxiv a license to display the preprint in perpetuity. All rights reserved. No reuse allowed without permission.

\begin{tabular}{|c|c|c|c|}
\hline $\begin{array}{l}\text { ECG FINDINGS OF } \\
\text { PERICARDITIS }\end{array}$ & $17 / 125(14 \%) \mathrm{N}=125$ & $2 / 50(4 \%) \mathrm{N}=50$ & 0.07 \\
\hline - $\quad$ PR-Segment Depression & $1 / 125(1 \%) \mathrm{N}=125$ & $0 / 50(0 \%) \mathrm{N}=50$ & 0.53 \\
\hline - $\quad$ ST Segment Elevation, Diffuse & $16 / 125(13 \%) \mathrm{N}=125$ & $2 / 50(4 \%) \mathrm{N}=50$ & 0.08 \\
\hline $\begin{array}{l}\text { PREMATURE VENTRICULAR } \\
\text { COMPLEX (ALL TYPES) }\end{array}$ & $18 / 125(14 \%) \mathrm{N}=125$ & $1 / 50(2 \%) \mathrm{N}=50$ & 0.02 \\
\hline - $\quad$ Premature Ventricular Complex & $17 / 125(14 \%) \mathrm{N}=125$ & $1 / 50(2 \%) \mathrm{N}=50$ & 0.02 \\
\hline $\begin{array}{l}\text { - Premature Ventricular Complex } \\
\text { Bigeminy }\end{array}$ & $2 / 125(2 \%) \mathrm{N}=125$ & $0 / 50(0 \%) \mathrm{N}=50$ & 0.37 \\
\hline SINUS MECHANISM & $107 / 125(85.6 \%) \mathrm{N}=125$ & $47 / 50(94 \%) \mathrm{N}=50$ & 0.08 \\
\hline - $\quad$ Sinus Tachycardia & $51 / 125(40.8 \%) \mathrm{N}=125$ & $21 / 50(42 \%) \mathrm{N}=50$ & 0.81 \\
\hline $\begin{array}{l}\text { REPOLARIZAITON } \\
\text { ABNORMALITIES }\end{array}$ & $53 / 125(42 \%) \mathrm{N}=125$ & $33 / 50(66 \%) \mathrm{N}=50$ & 0.005 \\
\hline $\begin{array}{l}\text { - ST Segment Elevation, } \\
\text { Regional }\end{array}$ & $8 / 125(6 \%) \mathrm{N}=125$ & $0 / 50(0 \%) \mathrm{N}=50$ & 0.07 \\
\hline $\begin{array}{l}\text { - ST Segment Depression, } \\
\text { Diffuse }\end{array}$ & $9 / 125(7 \%) \mathrm{N}=125$ & $2 / 50(4 \%) \mathrm{N}=50$ & 0.43 \\
\hline $\begin{array}{ll}\text { - } & \text { ST Segment Depression, } \\
\text { Regional }\end{array}$ & $7 / 125(6 \%) \mathrm{N}=125$ & $3 / 50(6 \%) \mathrm{N}=50$ & 0.92 \\
\hline - $\quad$ T Wave Inversions & $41 / 125(33 \%) \mathrm{N}=125$ & $29 / 50(58 \%) \mathrm{N}=50$ & 0.002 \\
\hline - T Wave Notching & $0 / 125(0 \%) \mathrm{N}=125$ & $1 / 50(2 \%) \mathrm{N}=50$ & 0.11 \\
\hline $\begin{array}{l}\text { SUPRAVENTRICULAR } \\
\text { ARRHYTHMIAError! Bookmark not } \\
\text { defined. }\end{array}$ & $11 / 125(9 \%) \mathrm{N}=125$ & $2 / 50(4 \%) \mathrm{N}=50$ & 0.27 \\
\hline $\begin{array}{ll}\text { - } & \text { Atrial FibrillationError! } \\
\text { Bookmark not defined. }\end{array}$ & $10 / 125(8 \%) \mathrm{N}=125$ & $1 / 50(2 \%) \mathrm{N}=50$ & 0.14 \\
\hline $\begin{array}{ll}\text { - } & \text { Atrial FlutterError! Bookmark } \\
\text { not defined. }\end{array}$ & $1 / 125(1 \%) \mathrm{N}=125$ & $1 / 50(2 \%) \mathrm{N}=50$ & 0.50 \\
\hline \multicolumn{4}{|l|}{ UNCATEGORIZED } \\
\hline Premature Atrial Complex & $8 / 125(6 \%) \mathrm{N}=125$ & $0 / 50(0 \%) \mathrm{N}=50$ & 0.07 \\
\hline Premature Junctional Complex & $1 / 125(1 \%) \mathrm{N}=125$ & $0 / 50(0 \%) \mathrm{N}=50$ & 0.53 \\
\hline Left Ventricular Hypertrophy & $21 / 125(17 \%) \mathrm{N}=125$ & $10 / 50(20 \%) \mathrm{N}=50$ & 0.62 \\
\hline Low QRS Voltage & $6 / 125(5 \%) \mathrm{N}=125$ & $2 / 50(4 \%) \mathrm{N}=50$ & 0.82 \\
\hline $\begin{array}{l}\text { P Wave Abnormality Suggestive of Left } \\
\text { Atrial Enlargement }\end{array}$ & $29 / 125(23 \%) \mathrm{N}=125$ & $14 / 50(28 \%) \mathrm{N}=50$ & 0.51 \\
\hline $\begin{array}{l}\text { P Wave Abnormality Suggestive of } \\
\text { Right Atrial Enlargement }\end{array}$ & $4 / 125(3 \%) \mathrm{N}=125$ & $10 / 50(20 \%) \mathrm{N}=50$ & $<0.001$ \\
\hline Q-waves, Pathological & $19 / 125(15 \%) \mathrm{N}=125$ & $4 / 50(8 \%) \mathrm{N}=50$ & 0.20 \\
\hline Accelerated Junctional Rhythm & $1 / 125(1 \%) \mathrm{N}=125$ & $0 / 50(0 \%) \mathrm{N}=50$ & 0.53 \\
\hline
\end{tabular}


medRxiv preprint doi: https://doi.org/10.1101/2021.02.28.21252516; this version posted March 2, 2021. The copyright holder for this preprint (which was not certified by peer review) is the author/funder, who has granted medRxiv a license to display the preprint in perpetuity. All rights reserved. No reuse allowed without permission.

\section{$514 \quad$ Figure 1: Outcomes by cumulative incidence of arrhythmia}

515

Cumulative incidence of all-cause mortality

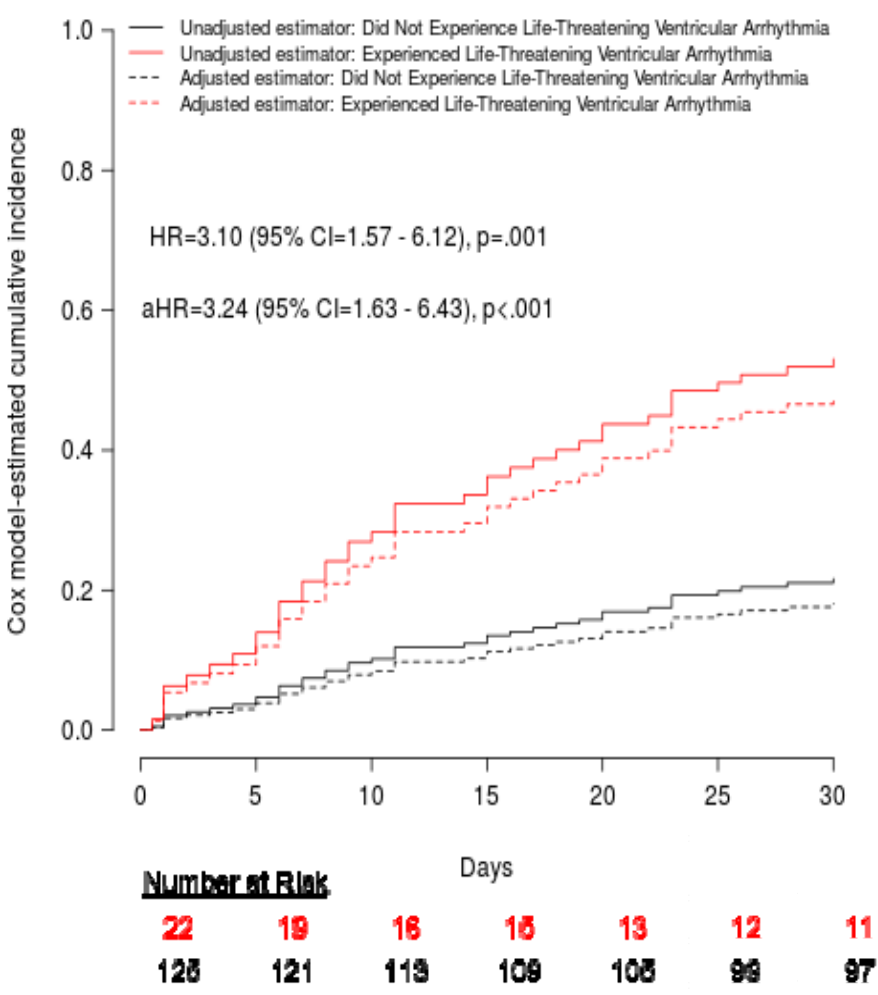

Cumulative incidence of myocarditis-related mortality

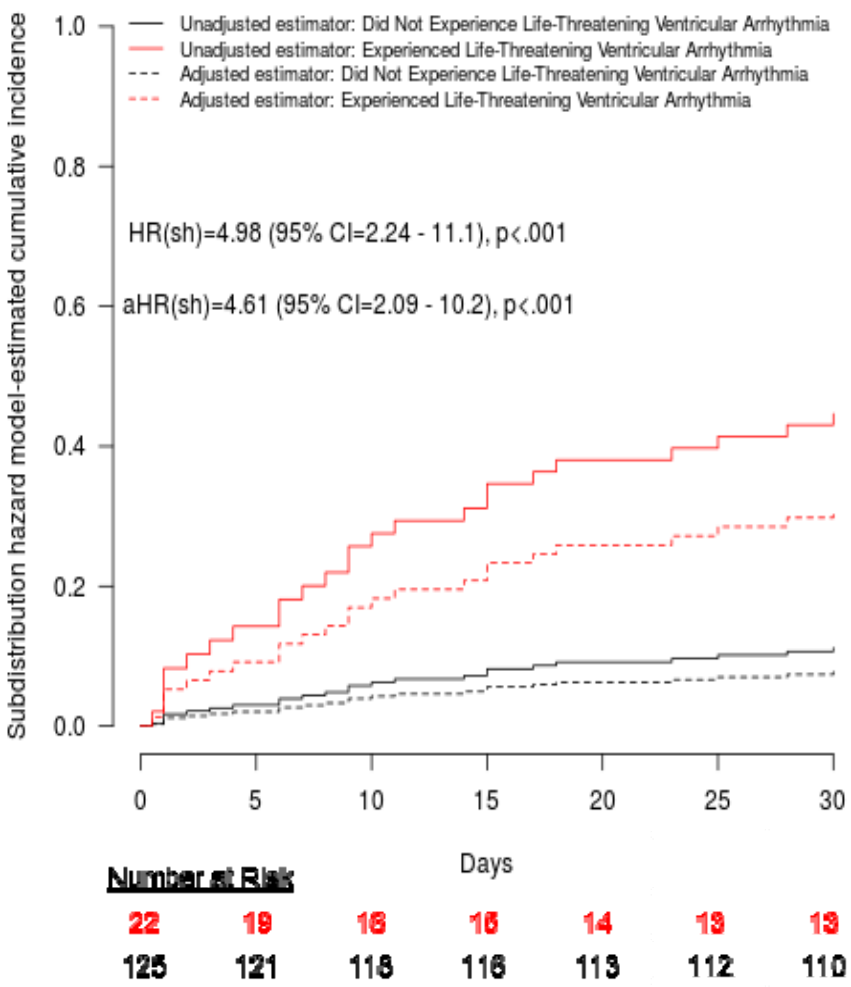

Cumulative incidence of all-cause mortality

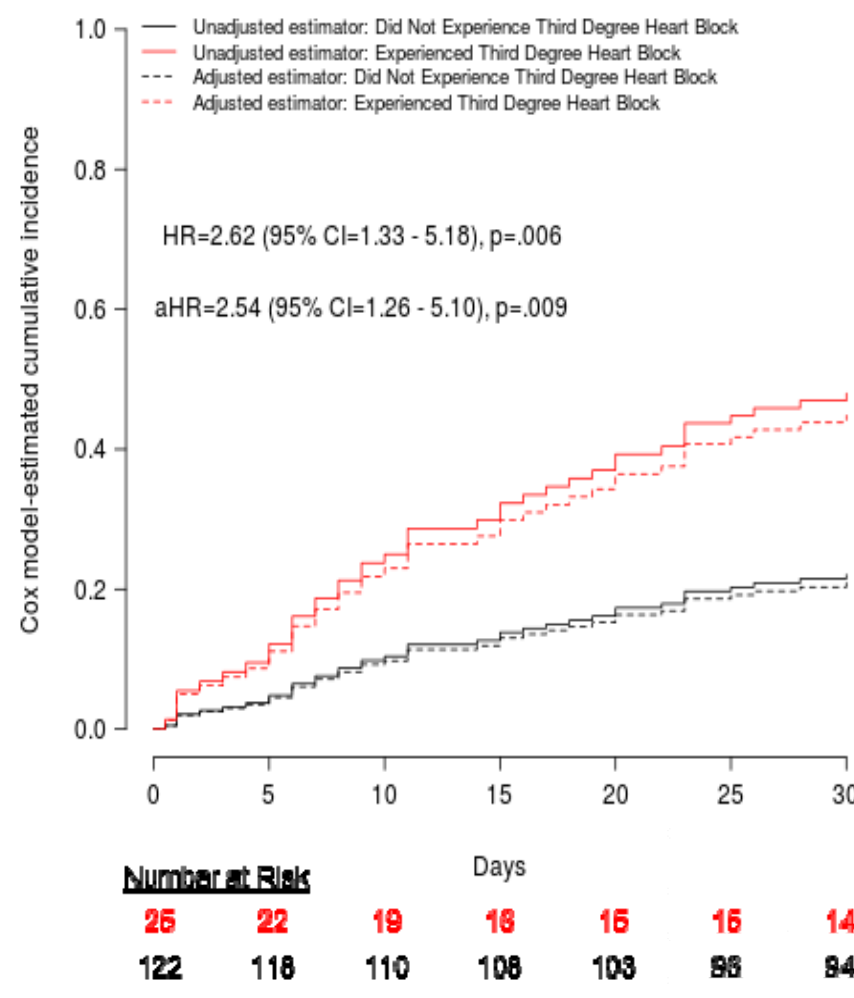

Cumulative incidence of myocarditis-related mortality

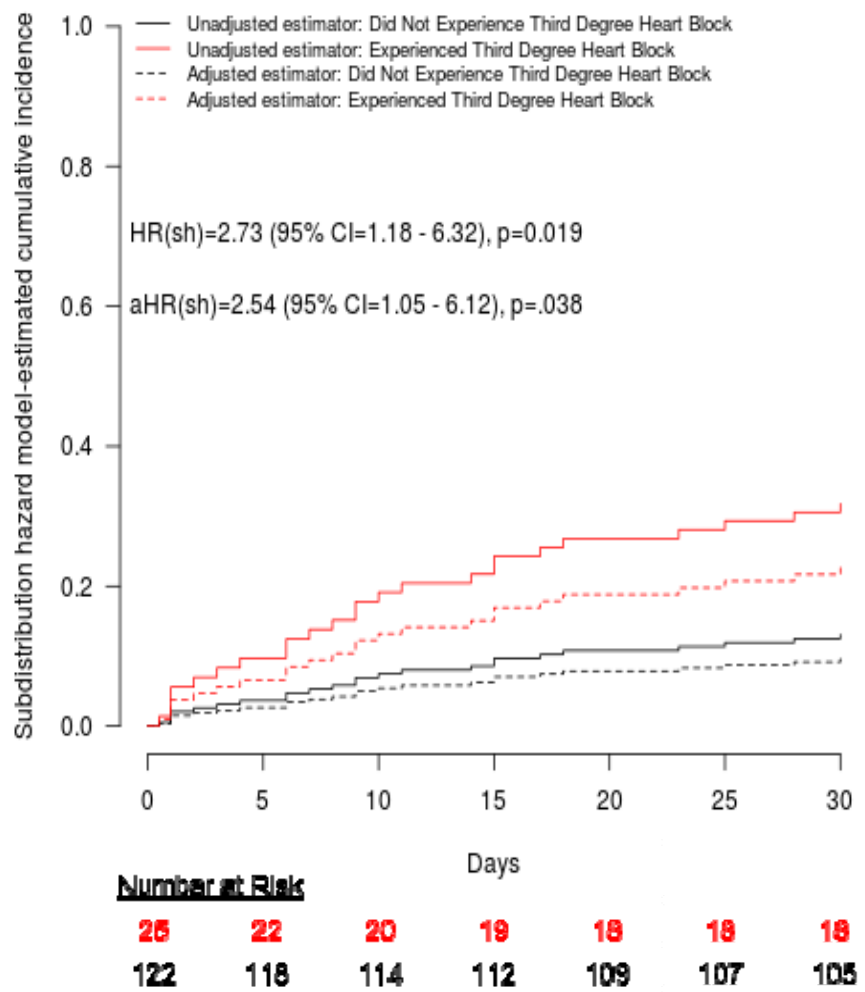


medRxiv preprint doi: https://doi.org/10.1101/2021.02.28.21252516; this version posted March 2, 2021. The copyright holder for this preprint (which was not certified by peer review) is the author/funder, who has granted medRxiv a license to display the preprint in perpetuity. All rights reserved. No reuse allowed without permission.

Figure 2: Outcomes by presenting ECG findings

Cumulative incidence of all-cause mortality

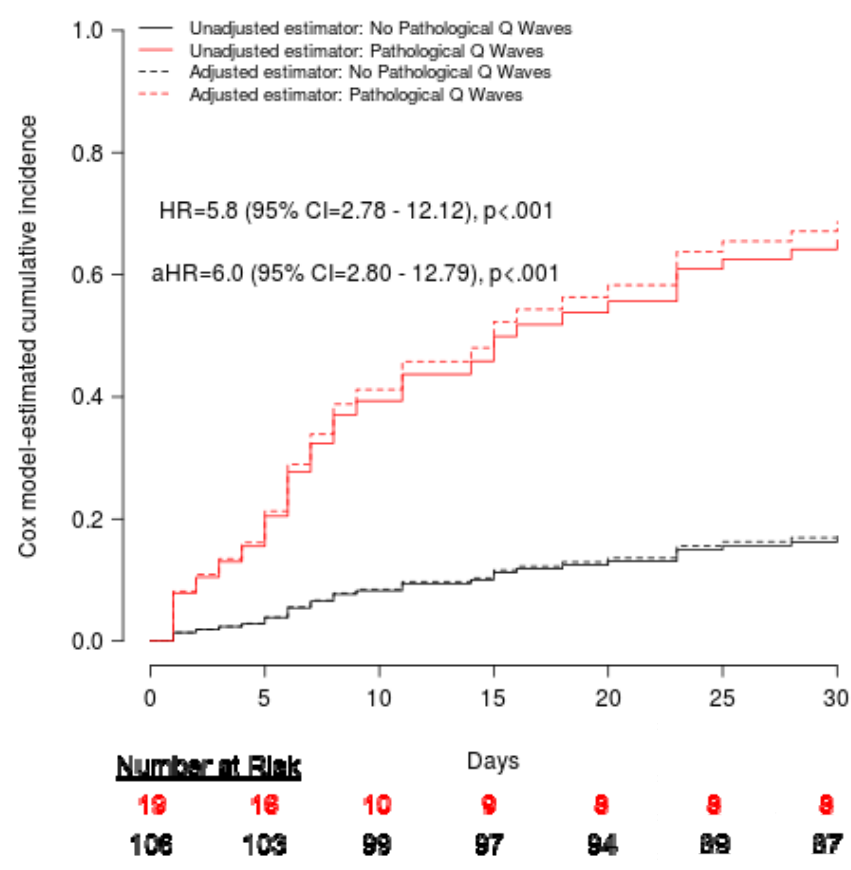

Cumulative incidence of myocarditis-related mortality

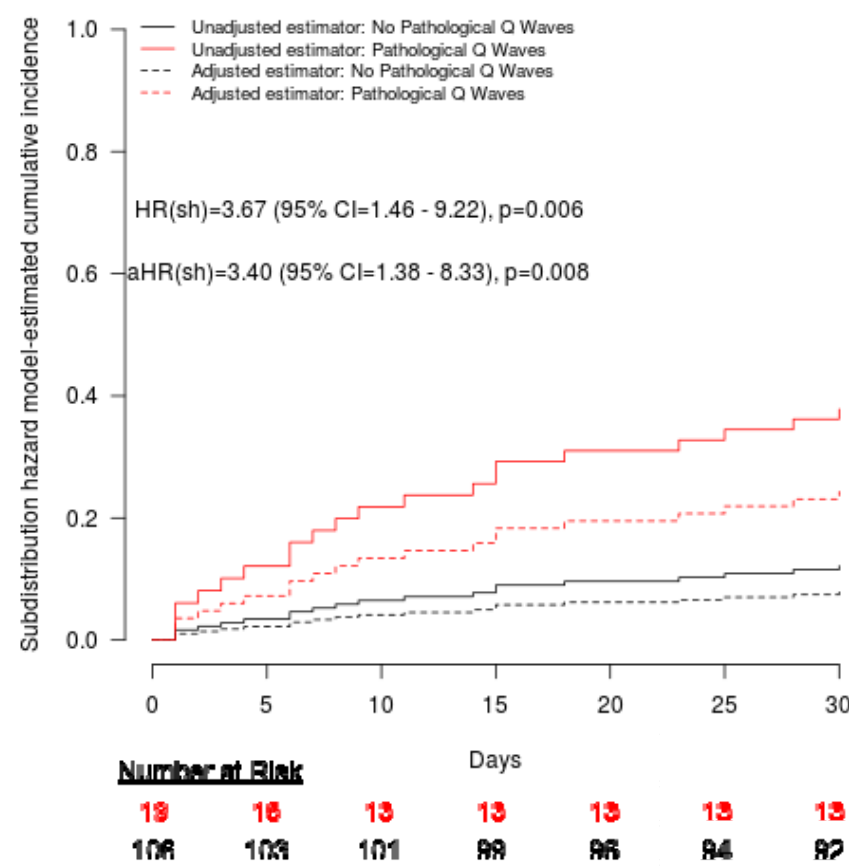

517

518
Cumulative incidence of all-cause mortality

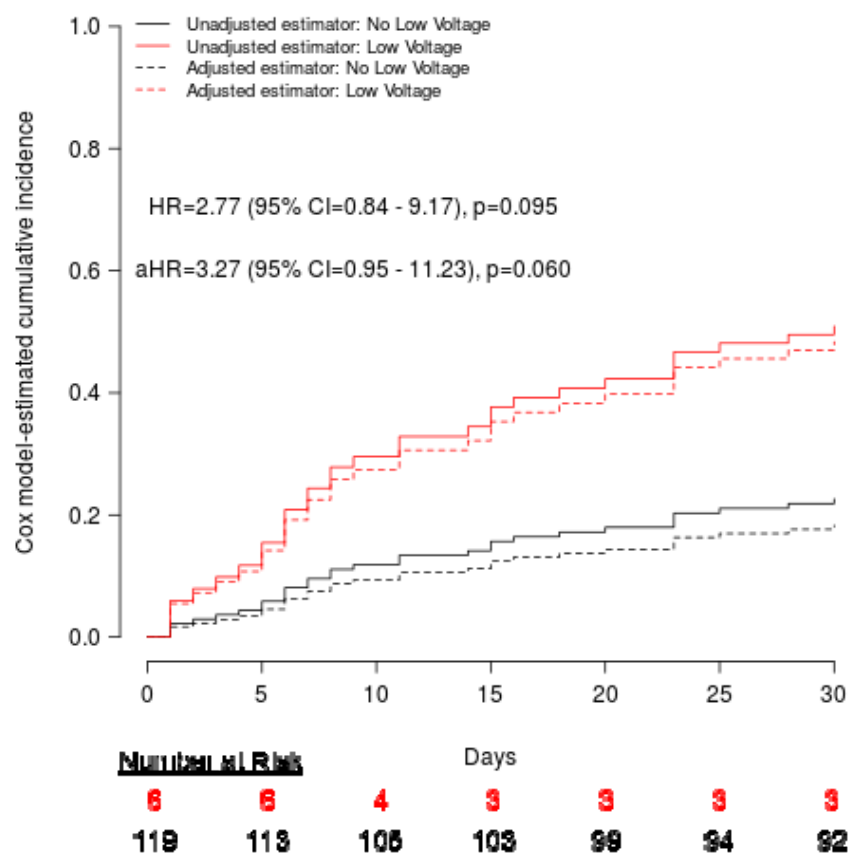

Cumulative incidence of myocarditis-related mortality

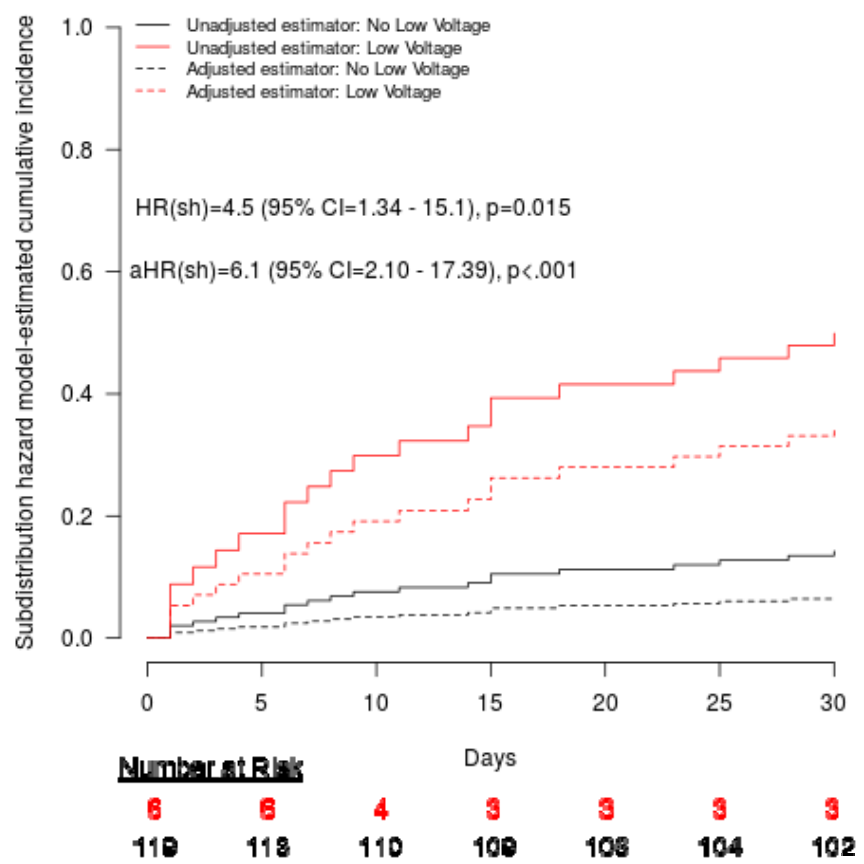




\section{Supplemental Data.}

\section{$520 \quad$ Supplemental Table 1. List of participating institutions}

\begin{tabular}{|c|}
\hline $\begin{array}{l}\text { AH-HP.Sorbonne University; Paris; France } \\
-\quad \text { Coauthors: Joe-Elie Salem, Stéphane Ederhy } \\
-\quad \text { Collaborators: Charlotte Fenioux, Baptiste Abbar, Yves Allenbach }\end{array}$ \\
\hline Allama Iqbal Medical College; Lahore; Pakistan ${ }^{*}$ \\
\hline $\begin{array}{l}\text { Assistance publique Hôpitaux Universitaires de Marseille Nord; Paris ; France } \\
\text { - } \quad \text { Coauthors: Jennifer Cautela, Franck Thuny }\end{array}$ \\
\hline $\begin{array}{l}\text { Barts Health NHS Trust; London; United Kingdom } \\
-\quad \text { Collaborators: Shanthini M Crusz, Arjun K Ghosh }\end{array}$ \\
\hline $\begin{array}{l}\text { Basaksehir Cam and Sakura State Hospital; Istanbul; Turkey } \\
\text { - Coauthors: Benay Ozbay }\end{array}$ \\
\hline $\begin{array}{l}\text { Baylor College of Medicine; Houston; USA } \\
-\quad \text { Collaborators: Tyler Moran }\end{array}$ \\
\hline $\begin{array}{l}\text { Beth Israel Deaconess Medical Center; Boston; USA } \\
-\quad \text { Coauthors: Aarti Asnani } \\
-\quad \text { Collaborators: Tyler Meheghan }\end{array}$ \\
\hline Brigham \& Women's Hospital; Boston; USA ${ }^{*}$ \\
\hline $\begin{array}{l}\text { Cedars-Sinai Medical Center; Los Angeles; USA } \\
\text { - Collaborators: Lawrence Piro }\end{array}$ \\
\hline Chibaken Saiseikai Narashino Hospital; Funabashi; Japan * \\
\hline $\begin{array}{l}\text { Chi-Mei Medical Center; Tainam ; Taiwan } \\
-\quad \text { Collaborators: Wei-Ting Chan }\end{array}$ \\
\hline $\begin{array}{l}\text { Cleveland Clinic; Cleveland; USA } \\
-\quad \text { Collaborators: Johnny Chahine }\end{array}$ \\
\hline $\begin{array}{l}\text { Dartmouth-Hitchcock Medical Center; Lebanon; USA } \\
\text { - Coauthors: Lauren Gilstrap }\end{array}$ \\
\hline Emory University Hospital; Atlanta; USA ${ }^{*}$ \\
\hline General Hospital of Chinese People's Liberation Army; Beijing; China ${ }^{*}$ \\
\hline Georgetown University Medical Center; Washington; USA* \\
\hline $\begin{array}{l}\text { Hartford Hospital; Hartford; USA } \\
-\quad \text { Collaborators: Ben Stringer }\end{array}$ \\
\hline $\begin{array}{l}\text { Heidelberg University Hospital; Heidelberg; Germany } \\
-\quad \text { Coauthors: Lorenz Lehmann; Daniel Finke }\end{array}$ \\
\hline $\begin{array}{l}\text { Hôpital Bichat, Paris, France } \\
-\quad \text { Coauthors: Dimitri Arangalage } \\
\text { Collaborator: Valérie Gounant }\end{array}$ \\
\hline Hôpital Europeen Georges Pompidou; Paris; France* \\
\hline $\begin{array}{l}\text { Hôpital Lariboisière; Paris; France } \\
-\quad \text { Collaborators: Martin Nicol }\end{array}$ \\
\hline $\begin{array}{l}\text { Hôpital Saint-Louis; Paris, France } \\
\text { - Collaborators: Barouyr Baroudjian }\end{array}$ \\
\hline $\begin{array}{l}\text { Institut Bergonié : Centre Régional de Lutte Contre le Cancer ; Bordeaux ; France } \\
\text { - Collaborators: Marie-Claire Zimmer }\end{array}$ \\
\hline $\begin{array}{l}\text { Institut de Cancérologie de l'Ouest; Saint Herblain; France } \\
-\quad \text { Collaborator : Elvire Mervoyer }\end{array}$ \\
\hline $\begin{array}{l}\text { International University of Health and Welfare Mita Hospital; Tokyo; Japan } \\
-\quad \text { Coauthors: Yuichi Tamura }\end{array}$ \\
\hline
\end{tabular}

\footnotetext{
data were collected from published cases in these institutions with no manual confirmation from for data completeness from authors
} 


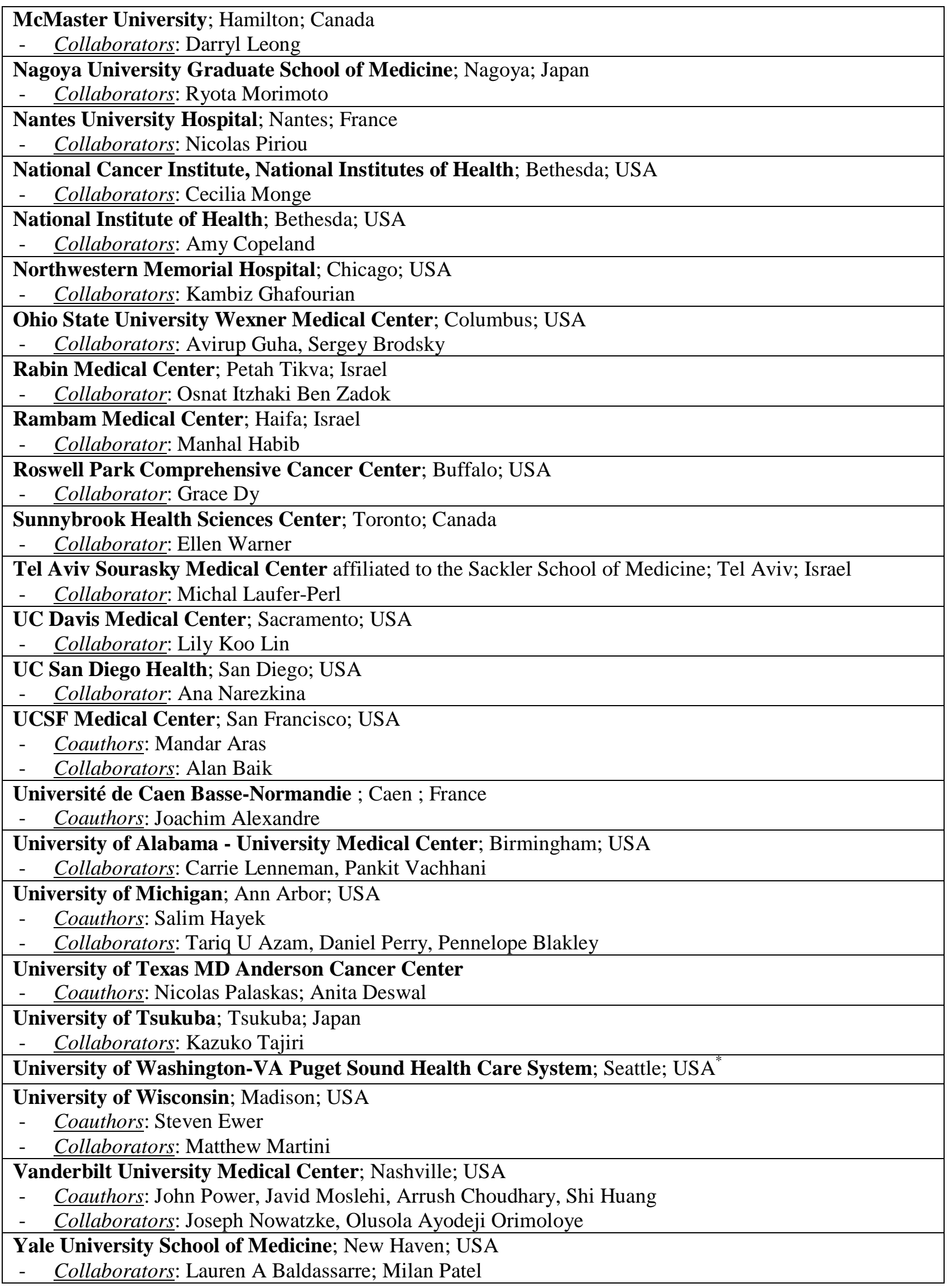


medRxiv preprint doi: https://doi.org/10.1101/2021.02.28.21252516; this version posted March 2, 2021. The copyright holder for this preprint (which was not certified by peer review) is the author/funder, who has granted medRxiv a license to display the preprint in perpetuity.

All rights reserved. No reuse allowed without permission.

\section{Supplemental Table 2: Glossary of qualitative ECG findings by category}

\section{CONDUCTION DISORDERS}

- Bundle Branch Block, Left (defined as QRS $\geq 120 \mathrm{~ms}$ + broad notched or slurred R wave in I, aVL, V5 \& V6) ${ }^{36}$

- Nonspecific or Unspecified Intraventricular Conduction Disturbance

- Bundle Branch Block, Right (defined as QRS $\geq 120 \mathrm{~ms}$; RSR' pattern in V1-V2; and slurred S wave in I, V6) ${ }^{36}$

- Escape Rhythm, Junctional

- Escape Rhythm, Ventricular

- Fascicular Block, Left Anterior (defined as QRS $<120 \mathrm{~ms}$, qR in aVL, R-peak time $\geq 45 \mathrm{~ms}$, frontal plane axis between $-45^{\circ}$ and $\left.-90^{\circ}\right)^{36}$

- Fascicular Block, Left Posterior (defined as QRS $<120 \mathrm{~ms}$, qR in III \& aVF, R-peak time $>45 \mathrm{ms,}$ frontal plane axis between $90^{\circ}$ and $\left.180^{\circ}\right)^{36}$

- Heart Block, First Degree (i.e. PR > 200ms)

- Heart Block, Second Degree Type I

- Heart Block, Second Degree Type II

- Heart Block, Third Degree

REPOLARIZATION ABNORMALITIES

- ST-Segment Depression, Diffuse (defined as $\geq 0.05 \mathrm{mV}$ below the baseline) ${ }^{37}$

- ST-Segment Depression, Regional (defined as $\geq 0.05 \mathrm{mV}$ below the baseline) ${ }^{37}$

- ST-Segment Elevation, Regional (defined as $\geq 0.1 \mathrm{mV}$ unless in leads V2 to V3 where defined as $\geq 0.2 \mathrm{mV}$ in men $\geq 40$ years, $\geq 2.5 \mathrm{mV}$ in men $<40$ years, and $\geq 0.15 \mathrm{mV}$ in women)

- T Wave Inversions

- $\mathrm{T}$ Wave Notching in $\geq 3$ leads (defined as bifid T-wave with a notch duration between the 2 peaks $\geq 40 \mathrm{~ms}$ and an amplitude $\geq 0.05 \mathrm{mV}$ )

- Tall $\mathrm{T}$ waves (defined as $>1 \mathrm{mV}$ in precordial leads or $>0.5 \mathrm{mV}$ in the limb leads)

\section{SINUS MECHANISM}

- Sinus Bradycardia (i.e. HR < 60 bpm)

- Normal Sinus Rhythm

- Sinus Tachycardia (i.e. HR > 100 bpm)

- Sinus Arrhythmia

ECG FEATURES SUGGESTIVE OF PERICARDITIS

- PR-Segment Depression (defined as $\geq 0.05 \mathrm{mV}$ PR depression from TP segment)

- ST-Segment Elevation, Diffuse (defined as $\geq 1 \mathrm{mV}$ unless in leads V2 to V3 where defined as $\geq 2 \mathrm{mV}$ in men $\geq 40$ years, $\geq 2.5 \mathrm{mV}$ in men $<40$ years, and $\geq 1.5 \mathrm{mV}$ in women)

\section{SUPRAVENTRICULAR ARRHYTHMIAS}

- Atrial Fibrillation

- Atrial Flutter

- AV (atrioventricular) Nodal Reentrant Tachycardia

- Multifocal Atrial Tachycardia

- Junctional Tachycardia

VENTRICULAR ARRHYTHMIA (ALL TYPES)

- Non-Sustained Ventricular Tachycardia (defined as 3 or more premature ventricular contractions for $<30$ seconds at a rate of $>100$ beats per minute without hemodynamic collapse)

+ all LIFE-THREATENING VENTRICULAR ARRHYTHMIAS (below) 
medRxiv preprint doi: https://doi.org/10.1101/2021.02.28.21252516; this version posted March 2, 2021. The copyright holder for this preprint (which was not certified by peer review) is the author/funder, who has granted medRxiv a license to display the preprint in perpetuity.

\section{LIFE-THREATENING VENTRICULAR ARRHYTHMIA}

- Sustained (i.e. duration > 30 seconds or requiring intervention due to hemodynamic compromise) Monomorphic Ventricular Tachycardia

- Sustained Polymorphic Ventricular Tachycardia

- Ventricular Fibrillation

- Sustained Torsade de Pointes

UNCATEGORIZED FEATURES

- Left Ventricular Hypertrophy (defined as sum of $\mathrm{S}$ wave in $\mathrm{V} 1+\mathrm{R}$ wave in $\mathrm{V} 5$ or $\mathrm{V} 6 \geq 35 \mathrm{mV}$ or $\mathrm{R}$ wave in aVL $\geq 11 \mathrm{mV}$ )

- Low QRS Voltage (defined as QRS voltage $<5 \mathrm{mV}$ in the limb leads and/or $<10 \mathrm{mV}$ in precordial leads)

- P Wave Abnormality Suggestive Of Left Atrial Enlargement [defined as P-wave duration (120 ms or more) OR widely notched $\mathrm{P}$ wave (40 $\mathrm{ms}$ or more) $]^{38}$

- P Wave Abnormality Suggestive Of Right Atrial Enlargement [defined as P wave in lead II (greater than $0.25 \mathrm{mV})$ OR P wave in V1 or V2(0.15 mV or more $)^{38}$

- Premature Atrial Complex

- Premature Junctional Complex

- Q Waves, Pathological [defined as Q-wave $\geq 0.03 \mathrm{~s}$ and $\geq 0.1 \mathrm{mV}$ deep or QS complex in leads I, II, aVL, aVF or V4-V6 in any 2 leads of a contiguous lead grouping (I, aVL; V1-V6; II, III, aVF).a $\mathrm{R}$ wave $>0.04 \mathrm{~s}$ in $\mathrm{V} 1-\mathrm{V} 2$ and $\mathrm{R} / \mathrm{S}>1$ with a concordant positive $\mathrm{T}$ wave in absence of conduction defect.] ${ }^{37}$ 
medRxiv preprint doi: https://doi.org/10.1101/2021.02.28.21252516; this version posted March 2, 2021. The copyright holder for this preprint (which was not certified by peer review) is the author/funder, who has granted medRxiv a license to display the preprint in perpetuity.

524 Supplemental Table 3: Cumulative incidence of arrhythmia throughout hospital stay for 125 525 ICI-myocarditis patients in ECG features quantitative outcome analysis

526 (Please refer to Supplemental Table 2 for full details on diagnostic criteria and categorization of 527 qualitative ECG features)

\begin{tabular}{|c|c|}
\hline & $\mathrm{n} / \mathrm{N}(\%)$ \\
\hline SINUS MECHANISM & $107 / 125(85.6 \%)$ \\
\hline - $\quad$ Normal Sinus Rhythm & $56 / 125(44.8 \%)$ \\
\hline - $\quad$ Sinus Bradycardia & $2 / 125(1.6 \%)$ \\
\hline - $\quad$ Sinus Tachycardia & $55 / 125(44.0 \%)$ \\
\hline - $\quad$ Sinus Arrhythmia & $1 / 125(0.8 \%)$ \\
\hline CONDUCTION DISORDERS & $87 / 125(69.6 \%)$ \\
\hline - $\quad$ Bundle Branch Block, Nonspecific & $8 / 125(6.4 \%)$ \\
\hline - $\quad$ Bundle Branch Block, Left Bundle & $23 / 125(18.4 \%)$ \\
\hline - $\quad$ Bundle Branch Block, Right Bundle & $45 / 125(36.0 \%)$ \\
\hline - $\quad$ Escape Rhythm, Ventricular & $4 / 125(3.2 \%)$ \\
\hline - $\quad$ Escape Rhythm, Junctional & $4 / 125(3.2 \%)$ \\
\hline - $\quad$ Fascicular Block, Left Anterior & $25 / 125(20.0 \%)$ \\
\hline - $\quad$ Fascicular Block, Left Posterior & $14 / 125(11.2 \%)$ \\
\hline - $\quad$ Heart Block, First Degree & $19 / 125(15.2 \%)$ \\
\hline - $\quad$ Heart Block, Second Degree Type I & $4 / 125(3.2 \%)$ \\
\hline - $\quad$ Heart Block, Second Degree Type II & $5 / 125(4.0 \%)$ \\
\hline - $\quad$ Heart Block, Third Degree & $19 / 125(15.2 \%)$ \\
\hline ECG FINDINGS OF PERICARDITIS & $18 / 125(14.4 \%)$ \\
\hline - $\quad$ PR-Segment Depression & $1 / 125(0.8 \%)$ \\
\hline - $\quad$ ST Segment Elevation, Diffuse & $17 / 125(13.6 \%)$ \\
\hline REPOLARIZATION ABNORMALITIES & $62 / 125(49.6 \%)$ \\
\hline - $\quad$ ST segment elevation, regional & $13 / 125(10.4 \%)$ \\
\hline - $\quad$ ST Segment Depression, Diffuse & $11 / 125(8.8 \%)$ \\
\hline - $\quad$ ST Segment Depression, Regional & $8 / 125(6.4 \%)$ \\
\hline - $\quad$ Tall T Waves & $1 / 125(0.8 \%)$ \\
\hline - $\quad$ T Wave Inversions & $45 / 125(36.0 \%)$ \\
\hline - $\quad$ T Wave Notching & $5 / 125(4.0 \%)$ \\
\hline VENTRICULAR EXCITABILITY (PVC or Ventricular Arrhythmia) & $42 / 125(33.6 \%)$ \\
\hline PREMATURE VENTRICULAR COMPLEX (ALL TYPES) & $33 / 125(26.4 \%)$ \\
\hline - $\quad$ Premature Ventricular Complex & $31 / 125(24.8 \%)$ \\
\hline - $\quad$ Premature Ventricular Complex Bigeminy & $5 / 125(4.0 \%)$ \\
\hline - $\quad$ Premature Ventricular Complex Trigeminy & $1 / 125(0.8 \%)$ \\
\hline VENTRICULAR ARRHYTMIAS (all types) & $18 / 125(14.4 \%)$ \\
\hline - Ventricular Tachycardia, Non-Sustained & $9 / 125(7.2 \%)$ \\
\hline - Ventricular Tachycardia, Sustained & $9 / 125(7.2 \%)$ \\
\hline LIFE-THREATENING VENTRICULAR ARRHYTHMIA & $15 / 125(12.0 \%)$ \\
\hline - $\quad$ Asystole & $4 / 125(3.2 \%)$ \\
\hline - $\quad$ Pulseless Electrical Activity & $4 / 125(3.2 \%)$ \\
\hline
\end{tabular}




\begin{tabular}{|c|c|}
\hline - $\quad$ Ventricular Fibrillation & $4 / 125(3.2 \%)$ \\
\hline - Ventricular Tachycardia Unspecified Morphology, Sustained & $5 / 125(4.0 \%)$ \\
\hline - Ventricular Tachycardia Monomorphic, Sustained & $5 / 125(4.0 \%)$ \\
\hline - Ventricular Tachycardia Polymorphic, Sustained & $1 / 125(0.8 \%)$ \\
\hline - Ventricular Tachycardia Torsade de Pointes, Sustained & $2 / 125(1.6 \%)$ \\
\hline SUPRA-VENTRICULAR ARRHYTHMIAS & $30 / 125(24.0 \%)$ \\
\hline - $\quad$ Atrial Fibrillation & $26 / 125(20.8 \%)$ \\
\hline - $\quad$ Atrial Flutter & $2 / 125(1.6 \%)$ \\
\hline - $\quad$ Multifocal Atrial Tachycardia & $2 / 125(1.6 \%)$ \\
\hline - $\quad$ AV Nodal Reentrant Tachycardia & $2 / 125(1.6 \%)$ \\
\hline - $\quad$ Junctional Tachycardia & $0 / 125(0.0 \%)$ \\
\hline \multicolumn{2}{|l|}{ UNCATEGORIZED } \\
\hline Accelerated Idioventricular Rhythm & $3 / 125(2.4 \%)$ \\
\hline Accelerated Junctional Rhythm & $1 / 125(0.8 \%)$ \\
\hline Left Ventricular Hypertrophy & $22 / 125(17.6 \%)$ \\
\hline Low QRS Voltage & $12 / 125(9.6 \%)$ \\
\hline Q-Waves, Pathological & $22 / 125(17.6 \%)$ \\
\hline P Wave Abnormality Suggestive of Left Atrial Enlargement & $29 / 125(23.2 \%)$ \\
\hline P Wave Abnormality Suggestive of Right Atrial Enlargement & $4 / 125(3.2 \%)$ \\
\hline Premature Atrial Complex & $14 / 125(11.2 \%)$ \\
\hline Premature Junctional Complex & $2 / 125(1.6 \%)$ \\
\hline Sinus Arrest / Sinus Pause & $2 / 125(1.6 \%)$ \\
\hline Placement of a Pacemaker and/or Defibrillator Within 30 days & $19 / 124(15.3 \%)$ \\
\hline In-Hospital Mortality & $33 / 125(26.4 \%)$ \\
\hline 30-Day All-Cause Mortality & $30 / 124(24.2 \%)$ \\
\hline $\begin{array}{l}\text { 30-Day Myocarditis-Related Mortality or Life-Threatening Ventricular } \\
\text { Arrhythmia }\end{array}$ & $28 / 124(22.6 \%)$ \\
\hline \multicolumn{2}{|l|}{ Cause of Death (of 30 patients with 30d all-cause mortality) } \\
\hline Myocarditis & $20 / 30(66.7 \%)$ \\
\hline Cancer Progression & $6 / 30(20 \%)$ \\
\hline Immune Related Adverse Event Other Than Cardiotoxicity ${ }^{*}$ & $6 / 30(20 \%)$ \\
\hline $\begin{array}{l}\text { - Non-Cardiac Myotoxicities Including Myasthenia Gravis-Like Syndrome } \\
\text { Associated with Diaphragmatic Failure }\end{array}$ & $5 / 6(83 \%)$ \\
\hline - Thrombocytopenia, Immune Related & $1 / 6(17 \%)$ \\
\hline Sepsis & $4 / 30(13 \%)$ \\
\hline Thromboembolic Event & $2 / 30(7 \%)$ \\
\hline Hemorrhage & $1 / 30(3 \%)$ \\
\hline Respiratory Failure (Other Than Diaphragmatic Failure) ${ }^{\dagger}$ & $2 / 30(7 \%)$ \\
\hline - Pulmonary Infection & $1 / 2(50 \%)$ \\
\hline - Acute Respiratory Distress Syndrome & $1 / 2(50 \%)$ \\
\hline Ischemic Stroke & $1 / 30(3 \%)$ \\
\hline Unknown & $1 / 30(3 \%)$ \\
\hline
\end{tabular}

$*$ note more than one cause may contribute to respiratory failure 
medRxiv preprint doi: https://doi.org/10.1101/2021.02.28.21252516; this version posted March 2, 2021. The copyright holder for this preprint (which was not certified by peer review) is the author/funder, who has granted medRxiv a license to display the preprint in perpetuity. All rights reserved. No reuse allowed without permission.

528 Supplemental Table 4: Presenting ECG of ICI-myocarditis as predictors of all-cause mortality, 529 myocarditis-related mortality, and composite outcome using unadjusted survival analyses

\begin{tabular}{|c|c|c|c|}
\hline & $\begin{array}{r}\text { Subdistribution Hazards } \\
\text { Model For 30d Myocarditis- } \\
\text { Related Mortality } \\
\end{array}$ & $\begin{array}{r}\text { Subdistribution Hazards } \\
\text { Model For 30d Composite } \\
\text { Outcome } \\
\end{array}$ & $\begin{array}{r}\text { Cox Proportional Hazard: } \\
\text { Model For 30d All-Caus } \\
\text { Mortalit! }\end{array}$ \\
\hline & $\begin{array}{r}\text { unadjusted HR(sh) }(95 \% \text { CI) p- } \\
\text { value }\end{array}$ & $\begin{array}{r}\text { unadjusted HR(sh) }(95 \% \text { CI) p- } \\
\text { value }\end{array}$ & $\begin{array}{r}\text { unadjusted HR (95\% CI) p } \\
\text { valui }\end{array}$ \\
\hline Heart Rate (bpm) & $1.01[0.99-1.03], \mathrm{p}=.35 \mathrm{~N}=125$ & $1.01[0.99-1.02], p=.40 \mathrm{~N}=125$ & $1.00[0.99-1.02], \mathrm{p}=.70 \mathrm{~N}=12$ : \\
\hline PR Length (ms) & $1.00[0.98-1.02], p=.97 \mathrm{~N}=107$ & $1.00[0.99-1.01], p=.76 \mathrm{~N}=107$ & $1.00[0.99-1.01], \mathrm{p}=.91 \mathrm{~N}=10^{\prime}$ \\
\hline QTcF Length (ms) & $1.00[0.99-1.01], p=.66 \mathrm{~N}=122$ & $1.00[0.99-1.01], p=.52 \mathrm{~N}=122$ & $1.01[1.00-1.01], \mathrm{p}=.22 \mathrm{~N}=12^{\prime}$ \\
\hline QRS Length (ms) & $1.01[0.99-1.02], p=.51 \mathrm{~N}=125$ & $1.01[1.00-1.02], \mathrm{p}=.11 \mathrm{~N}=125$ & $1.00[0.99-1.02], \mathrm{p}=.51 \mathrm{~N}=12$ : \\
\hline Sokolow-Lyon Index (mV) & $0.55[0.28-1.06], \mathrm{p}=.08 \mathrm{~N}=124$ & $0.51[0.30-0.87], \mathrm{p}=.01 \mathrm{~N}=124$ & $0.59[0.35-0.98], \mathrm{p}=.04 \mathrm{~N}=12$ \\
\hline $\begin{array}{l}\text { CONDU } \\
\text { DISORD }\end{array}$ & $1.84[0.68-5.00], p=.23 \mathrm{~N}=125$ & $6], p=.02 \mathrm{~N}=125$ & , $\mathrm{p}=.21 \mathrm{~N}=12:$ \\
\hline Bundle Branch Block, Left Bundle & $0.9[0.27-2.99], \mathrm{p}=.87 \mathrm{~N}=125$ & 2], $\mathrm{p}=.38 \mathrm{~N}=125$ & $\mathrm{p}=.91 \mathrm{~N}=12$ : \\
\hline Bundle Branch Block, Right Bundle & $1.67[0.7-3.99], p=.25 \mathrm{~N}=125$ & 7], $\mathrm{p}=.04 \mathrm{~N}=125$ & $.17], \mathrm{p}=.24 \mathrm{~N}=12$ \\
\hline Fascicular Block, Left Anterior & $1.47[0.54-4.04], \mathrm{p}=.45 \mathrm{~N}=125$ & $1.79[0.81-3.96], \mathrm{p}=.15 \mathrm{~N}=125$ & $0.84[0.32-2.20], \mathrm{p}=.73 \mathrm{~N}=12$ \\
\hline Fascicular Block, Left Posterior & $1.48[0.47-4.69], p=.5 \mathrm{~N}=125$ & $1.60[0.55-4.69], p=.39 \mathrm{~N}=125$ & $8], \mathrm{p}=.68 \mathrm{~N}=12$ ? \\
\hline Heart Block, First Degree & $58[0.53-4.74], \mathrm{p}=.41 \mathrm{~N}=125$ & $=.18$ & $=.90 \mathrm{~N}=12^{\prime}$ \\
\hline Ecg Findings Of Peri & $0.68[0.16-2.84], p=.59 \mathrm{~N}=125$ & $1.08[0.38-3.07], p=.89 \mathrm{~N}=125$ & $0.67[0.20-2.22], \mathrm{p}=.52 \mathrm{~N}=12$ : \\
\hline ST Segmen & $0.73[0.17-3.06], p=.67 \mathrm{~N}=125$ & $1.16[0.41-3.32], \mathrm{p}=.78 \mathrm{~N}=125$ & $0.73[0.22-2.40], \mathrm{p}=.60 \mathrm{~N}=12$ \\
\hline $\begin{array}{l}\text { PREMATURE VENTRICULAR } \\
\text { COMPLEX (ALL TYPES) }\end{array}$ & $1.56[0.53-4.56], p=.42 \mathrm{~N}=125$ & 22], $\mathrm{p}=.21 \mathrm{~N}=125$ & 6], $\mathrm{p}=.70 \mathrm{~N}=12$ : \\
\hline Premature Ventricular Complex & $1.13[0.34-3.74], p=.84 \mathrm{~N}=125$ & $1.41[0.56-3.55], p=.46 \mathrm{~N}=125$ & $0.95[0.33-2.72], \mathrm{p}=.93 \mathrm{~N}=12$ : \\
\hline SINUS MECHANISM & $0.55[0.21-1.48], \mathrm{p}=.24 \mathrm{~N}=125$ & $0.68[0.28-1.62], p=.38 \mathrm{~N}=125$ & $0.77[0.31-1.87], \mathrm{p}=.56 \mathrm{~N}=12$ \\
\hline Normal Sinus Rhythm & $0.39[0.14-1.05], p=.06 \mathrm{~N}=125$ & $0.56[0.26-1.21], p=.14 \mathrm{~N}=125$ & $0.58[0.27-1.23], \mathrm{p}=.15 \mathrm{~N}=12$ \\
\hline Sinus Tachycardia & $1.62[0.68-3.84], p=.28 \mathrm{~N}=125$ & $1.39[0.67-2.88], p=.38 \mathrm{~N}=125$ & $1.46[0.71-3.00], \mathrm{p}=.30 \mathrm{~N}=12$ : \\
\hline $\begin{array}{l}\text { REPOLARIZATION } \\
\text { ABNORMALITIES }\end{array}$ & $1.38[0.58-3.29], p=.47 \mathrm{~N}=125$ & $1.39[0.67-2.88], \mathrm{p}=.37 \mathrm{~N}=125$ & $1.44[0.70-2.94], \mathrm{p}=.32 \mathrm{~N}=12$. \\
\hline ST Segment Depression, Diffuse & $0.68[0.09-4.95], p=.70 \mathrm{~N}=125$ & $0.45[0.06-3.25], p=.43 \mathrm{~N}=125$ & $1.64[0.50-5.41], \mathrm{p}=.42 \mathrm{~N}=12$ : \\
\hline ST Segment Depression, Regional & $0.94[0.11-7.73], p=.95 \mathrm{~N}=125$ & $1.37[0.33-5.68], p=.67 \mathrm{~N}=125$ & $0.59[0.08-4.33], \mathrm{p}=.61 \mathrm{~N}=12$. \\
\hline T Wave Inversions & $1.74[0.73-4.15], p=.21 \mathrm{~N}=125$ & $1.34[0.64-2.80], p=.44 \mathrm{~N}=125$ & $1.43[0.69-2.97], \mathrm{p}=.34 \mathrm{~N}=12$ \\
\hline $\begin{array}{l}\text { SUPRAVENTRICULAR } \\
\text { ARRHYTHMIA }^{\dagger}\end{array}$ & $2.86[1.00-8.2], \mathrm{p}=.05 \mathrm{~N}=125$ & $2.40[1.00-5.75], p=.05 \mathrm{~N}=125$ & $2.24[0.86-5.85], \mathrm{p}=.10 \mathrm{~N}=12$. \\
\hline Atrial Fibrillation $^{\dagger}$ & $2.25[0.66-7.64], p=.19 \mathrm{~N}=125$ & $2.06[0.76-5.54], p=.15 \mathrm{~N}=125$ & $1.93[0.67-5.54], \mathrm{p}=.22 \mathrm{~N}=12$ : \\
\hline & & & \\
\hline Premature Atrial Complex & $2.84[0.91-8.85], p=.07 \mathrm{~N}=125$ & $1.76[0.61-5.09], p=.29 \mathrm{~N}=125$ & $1.74[0.53-5.75], \mathrm{p}=.36 \mathrm{~N}=12$ \\
\hline Left Ventricular Hypertrophy & $0.87[0.26-2.95], p=.82 \mathrm{~N}=125$ & $0.55[0.17-1.77], p=.32 \mathrm{~N}=125$ & $0.52[0.16-1.71], \mathrm{p}=.28 \mathrm{~N}=12$ : \\
\hline Low QRS Voltage & $4.50[1.34-15.12], \mathrm{p}=.02 \mathrm{~N}=125$ & $2.57[0.90-7.28], \mathrm{p}=.08 \mathrm{~N}=125$ & $2.77[0.84-9.17], \mathrm{p}=.10 \mathrm{~N}=12$ ؛ \\
\hline $\begin{array}{l}\text { P Wave Abnormality Suggestive of } \\
\text { Left Atrial Enlargement }\end{array}$ & $1.36[0.54-3.40], \mathrm{p}=.51 \mathrm{~N}=125$ & $1.14[0.49-2.67], p=.76 \mathrm{~N}=125$ & $0.94[0.41-2.20], \mathrm{p}=.89 \mathrm{~N}=12$ : \\
\hline $\begin{array}{l}\text { P Wave Abnormality Suggestive of } \\
\text { Right Atrial Enlargement }\end{array}$ & N/A & N/A & $\begin{array}{r}0.01[0-66336310], \mathrm{p}=.6 \\
\mathrm{~N}=12\end{array}$ \\
\hline Q Waves, Pathological & 3.67 [1.46-9.22], $\mathrm{p}=.006 \mathrm{~N}=125$ & $2.10[0.90-4.89], \mathrm{p}=.09 \mathrm{~N}=125$ & $\begin{array}{r}5.80[2.78-12.12], \mathrm{p}<.00] \\
\mathrm{N}=12:\end{array}$ \\
\hline
\end{tabular}

When multiple eligible ECG were available, ECG without complete heart block or supraventricular arrhythmias were preferentially selected for this analysis focusing on PR, QRS and QTc measurements. Please see Table 1 for cumulative incidence of arrhythmias in ICI-myocarditis and Supplemental-Table-3 for cumulative incidence of arrhythmias in ACR. 


\begin{tabular}{|c|c|}
\hline & $\begin{array}{r}\text { Cox Proportional Hazards } \\
\text { Model For 30d All-Cause } \\
\text { Mortality: } \\
\text { HR [95\% CI], P-Value }\end{array}$ \\
\hline Heart Rate (bpm) & $1.01[0.99-1.02], p=.40 \mathrm{~N}=125$ \\
\hline PR Length (ms) & $1.00[0.99-1.01], p=.55 \mathrm{~N}=107$ \\
\hline QTcF Length (ms) & $1.00[1.00-1.01], \mathrm{p}=.36 \mathrm{~N}=122$ \\
\hline QRS Length (ms) & $1.00[0.99-1.01], \mathrm{p}=.90 \mathrm{~N}=125$ \\
\hline Sokolow-Lyon Index $(\mathrm{mV})$ & $0.57[0.34-0.94], p=.03 \mathrm{~N}=124$ \\
\hline CONDUCTION DISORDERS $^{\dagger}$ & $1.56[0.69-3.53], \mathrm{p}=.29 \mathrm{~N}=125$ \\
\hline - $\quad$ Bundle Branch Block, Left Bundle & $1.00[0.38-2.62], \mathrm{p}=.99 \mathrm{~N}=125$ \\
\hline - $\quad$ Bundle Branch Block, Right Bundle & $1.48[0.71-3.06], \mathrm{p}=.29 \mathrm{~N}=125$ \\
\hline - $\quad$ Fascicular Block, Left Anterior & $0.85[0.32-2.25], \mathrm{p}=.75 \mathrm{~N}=125$ \\
\hline - $\quad$ Fascicular Block, Left Posterior & $1.34[0.47-3.85], \mathrm{p}=.59 \mathrm{~N}=125$ \\
\hline - $\quad$ Heart Block, First Degree & $0.83[0.28-2.40], \mathrm{p}=.72 \mathrm{~N}=125$ \\
\hline ECG Findings Of Pericarditis & $0.75[0.22-2.51], \mathrm{p}=.64 \mathrm{~N}=125$ \\
\hline - $\quad$ ST Segment Elevation, Diffuse & $0.83[0.25-2.81], \mathrm{p}=.76 \mathrm{~N}=125$ \\
\hline PREMATURE VENTRICULAR COMPLEX (ALL TYPES) & $1.01[0.37-2.75], p=.99 \mathrm{~N}=125$ \\
\hline - $\quad$ Premature Ventricular Complex & $0.77[0.26-2.30], p=.64 \mathrm{~N}=125$ \\
\hline SINUS MECHANISM & $0.77[0.31-1.89], \mathrm{p}=.56 \mathrm{~N}=125$ \\
\hline - $\quad$ Normal Sinus Rhythm & $0.50[0.23-1.09], \mathrm{p}=.08 \mathrm{~N}=125$ \\
\hline - $\quad$ Sinus Tachycardia & $1.67[0.80-3.49], \mathrm{p}=.17 \mathrm{~N}=125$ \\
\hline REPOLARIZATION ABNORMALITIES & $1.52[0.74-3.12], \mathrm{p}=.26 \mathrm{~N}=125$ \\
\hline ST Segment Depression, Diffuse & $1.60[0.48-5.30], p=.44 \mathrm{~N}=125$ \\
\hline ST Segment Depression, Regional & $0.53[0.07-3.90], \mathrm{p}=.53 \mathrm{~N}=125$ \\
\hline T Wave Inversions & $1.49[0.71-3.12], \mathrm{p}=.29 \mathrm{~N}=125$ \\
\hline SUPRAVENTRICULAR ARRHYTHMIA ${ }^{\dagger}$ & $2.21[0.84-5.79], \mathrm{p}=.11 \mathrm{~N}=125$ \\
\hline - Atrial Fibrillation ${ }^{\dagger}$ & $1.83[0.63-5.27], \mathrm{p}=.27 \mathrm{~N}=125$ \\
\hline \multicolumn{2}{|l|}{ UNCATEGORIZED } \\
\hline Premature Atrial Complex & $1.59[0.47-5.38], \mathrm{p}=.46 \mathrm{~N}=125$ \\
\hline Left Ventricular Hypertrophy & $0.49[0.15-1.61], \mathrm{p}=.24 \mathrm{~N}=125$ \\
\hline Low QRS Voltage & $3.27[0.95-11.23], p=.06 \mathrm{~N}=125$ \\
\hline P Wave Abnormality Suggestive of Left Atrial Enlargement & $1.10[0.46-2.63], p=.83 \mathrm{~N}=125$ \\
\hline P Wave Abnormality Suggestive of Right Atrial Enlargement & $0.01[0-77149830], p=.66 \mathrm{~N}=125$ \\
\hline Q Waves, Pathological & $5.98[2.8-12.79], \mathrm{p}<.001 \mathrm{~N}=125$ \\
\hline
\end{tabular}

\footnotetext{
* $\quad$ Please see Table 1 for cumulative incidence of arrhythmias in ICI-myocarditis and Supplemental-Table-3 for cumulative incidence of arrhythmias in ACR.

$\dagger \quad$ When multiple eligible ECG were available, ECG without complete heart block or supraventricular arrhythmias were preferentially selected for this analysis focusing on PR, QRS and QTc measurements. Please see Table 1 for cumulative incidence of arrhythmias in ICI-myocarditis and Supplemental-Table-3 for cumulative incidence of arrhythmias in ACR.
} 
medRxiv preprint doi: https://doi.org/10.1101/2021.02.28.21252516; this version posted March 2, 2021. The copyright holder for this preprint (which was not certified by peer review) is the author/funder, who has granted medRxiv a license to display the preprint in perpetuity.

\section{Supplemental Table 6: Baseline characteristics of acute cellular rejection cohort}

\begin{tabular}{|c|c|}
\hline & Med (IQR) N; n/N (\%) \\
\hline Recipient Age, Years & $51(43-62) \mathrm{N}=50$ \\
\hline Female Recipient & $18 / 50(36 \%)$ \\
\hline \multicolumn{2}{|l|}{ Reason for Transplant } \\
\hline - Dilated Cardiomyopathy & $4 / 50(8 \%)$ \\
\hline - Ischemic Cardiomyopathy & $18 / 50(36 \%)$ \\
\hline - $\quad$ Amyloidosis & $1 / 50(2 \%)$ \\
\hline - $\quad$ Restrictive Cardiomyopathy & $1 / 50(2 \%)$ \\
\hline - $\quad$ Congenital Heart Disease & $4 / 50(8 \%)$ \\
\hline - $\quad$ Non-Ischemic Cardiomyopathy, Not Otherwise Specified & $17 / 50(34 \%)$ \\
\hline - Hypertrophic Cardiomyopathy & $2 / 50(4 \%)$ \\
\hline - Other & $3 / 50(6 \%)$ \\
\hline Donor Age & $29.0(22.0-37.0) \mathrm{N}=50$ \\
\hline Female Donor & $13 / 50(26 \%)$ \\
\hline Known Cardiac Allograft Vasculopathy & $11 / 50(22 \%)$ \\
\hline \multicolumn{2}{|l|}{ Induction Therapy } \\
\hline - $\quad$ Basiliximab (Simulect) & $26 / 50(52 \%)$ \\
\hline - $\quad$ Thymoglobulin (ATG) & $3 / 50(6 \%)$ \\
\hline$-\quad$ None & $20 / 50(40 \%)$ \\
\hline - Other & $1 / 50(2 \%)$ \\
\hline \multicolumn{2}{|l|}{ Background/Maintenance Immunosuppressive Regimen } \\
\hline - $\quad$ Prednisone + Tacrolimus + Mycophenolate & $42 / 50(84 \%)$ \\
\hline - $\quad$ Prednisone + Cyclosporine + Mycophenolate & $3 / 50(6 \%)$ \\
\hline - Other & $5 / 50(10 \%)$ \\
\hline Days from Transplant To Rejection & $145(26-283) \mathrm{N}=50$ \\
\hline \multicolumn{2}{|l|}{ Acute Cellular Rejection Grading Scheme $\mathrm{S}^{21}$} \\
\hline - $\quad$ 2R, Moderate & $46 / 50(92 \%)$ \\
\hline - $3 \mathrm{R}$, Severe & $4 / 50(8 \%)$ \\
\hline Days from Transplant To ECG & $145(28-283) \mathrm{N}=50$ \\
\hline Days from Biopsy To ECG & $0(0-1)$ \\
\hline 30-Day All-Cause Mortality & $0 / 50(0 \%)$ \\
\hline $\begin{array}{l}\text { Placement of A Pacemaker and/or Defibrillator for ACR Related } \\
\text { Arrhythmias Within } 30 \text { Days Of Diagnosis }\end{array}$ & $0 / 50(0 \%)$ \\
\hline $\begin{array}{l}\text { Pacemaker Without Defibrillator for ACR Related Arrhythmias } \\
\text { Within } 30 \text { Days Of Diagnosis }\end{array}$ & $0 / 50(0 \%)$ \\
\hline Admitted During or As A Result Of ACR & $29 / 50(58.0 \%)$ \\
\hline Length of Stay (Days) & $12(5-21) \mathrm{N}=29$ \\
\hline $\begin{array}{l}\text { Reduced LVEF At Admission Or During Hospital Stay For ACR } \\
\text { (Excluding Pre-Transplant LVEF)* }\end{array}$ & $4 / 28(14.3 \%)$ \\
\hline In-Hospital Mortality* & $0 / 29(0 \%)$ \\
\hline \multicolumn{2}{|c|}{$\begin{array}{l}\text { Arrhythmias at Any Point During Hospitalization (If Applicable) Or At Presenting ECG } \\
\text { (Please Refer To Supplemental Table } 2 \text { For Criteria / Classification) }\end{array}$} \\
\hline $\begin{array}{l}\text { Supraventricular Arrhythmia } \\
-\quad \text { Atrial Fibrillation }\end{array}$ & $\begin{array}{r}6 / 50(12 \%) \\
3 / 50(6 \%)\end{array}$ \\
\hline
\end{tabular}

* This refers to the subset of admitted patients 
medRxiv preprint doi: https://doi.org/10.1101/2021.02.28.21252516; this version posted March 2, 2021. The copyright holder for this preprint (which was not certified by peer review) is the author/funder, who has granted medRxiv a license to display the preprint in perpetuity. All rights reserved. No reuse allowed without permission.

\begin{tabular}{|l|r|}
\hline$-\quad$ Atrial Flutter & $2 / 50(4 \%)$ \\
$-\quad$ Multifocal Atrial Tachycardia & $1 / 50(2 \%)$ \\
\hline Conduction Disorder & $34 / 50(68 \%)$ \\
$-\quad$ Bundle Branch or Fascicular Blocks & $33 / 50(66 \%)$ \\
$-\quad$ First-Degree Heart Block & $6 / 50(12 \%)$ \\
$-\quad$ Second-Degree Heart Block & $0 / 50(0 \%)$ \\
$-\quad$ Third-Degree Heart Block & $0 / 50(0 \%)$ \\
\hline ECG Finding of Pericarditis (PR Depression Or Diffuse ST & $2 / 50(4 \%)$ \\
Elevations) & \\
\hline Repolarization Abnormalities (ST-Segment Or T-Wave Changes) & $33 / 50(66 \%)$ \\
\hline Premature Ventricular Complexes (Any Type) & $6 / 50(12 \%)$ \\
\hline Ventricular Arrhythmias (Any Type; Sustained or Non- & $5 / 50(10 \%)$ \\
Sustained) & $1 / 50(2 \%)$ \\
\hline Life-Threatening Ventricular Arrhythmias & $0 / 50(0 \%)$ \\
$-\quad$ Asystole & $0 / 50(0 \%)$ \\
- Pulseless Electrical Activity & $0 / 50(0 \%)$ \\
- Ventricular Fibrillation & $0 / 50(0 \%)$ \\
- Ventricular Tachycardia Unspecified Morphology, Sustained & $1 / 50(2 \%)$ \\
- Ventricular Tachycardia Monomorphic, Sustained & $0 / 50(0 \%)$ \\
- Ventricular Tachycardia Polymorphic, Sustained & $0 / 50(0 \%)$ \\
\hline$-\quad$ Ventricular Tachycardia Torsade De Pointes, Sustained & $1 / 50(2 \%)$ \\
\hline Third-Degree Heart Block and/or Life-Threatening Ventricular & \\
Arrhythmia & \\
\hline
\end{tabular}


medRxiv preprint doi: https://doi.org/10.1101/2021.02.28.21252516; this version posted March 2, 2021. The copyright holder for this preprint (which was not certified by peer review) is the author/funder, who has granted medRxiv a license to display the preprint in perpetuity.

\section{Supplemental Data Methods 1: Systematic review search terms}

539 Pubmed, Scopus, and Google Scholar were queried for case reports published between 1/1/2008 and 5/21/2019 with the search terms myocarditis, cardiotoxicity or cardiac toxicity in addition to (AND) at least one of the following: immune checkpoint inhibitor, pembrolizumab, ipilimumab, nivolumab, avelumab, atezolizumab, durvalumab, tremelimumab, anti-CTLA-4, anti-PD-L1, anti-PD-1, CTLA-4 inhibitor, PD-L1 inhibitor, OR PD-1 inhibitor.

\section{Supplemental Data Methods 2: ECG interval measurement}

The QT interval was measured using the tangent method from the beginning of the QRS complex to the end of the T-wave. Lead II was preferentially used, but when unsuitable, V5 and V6 were used. The average of three consecutive PQRST complexes was used for each interval's measurements. PVCs were excluded. In the rare cases in which three consecutive complexes were not available, two complexes were used. The heart rate corrected QT interval (QTc) was calculated using Bazett's (QTcB=QT interval/ ) and Fredericia's formula (QTcF=QT interval/(RR interval) ${ }^{1 / 3}$.

Figure: ECG measurement with EP Calipers application (note that values used were an average of measurements across three consecutive PQRST complexes)

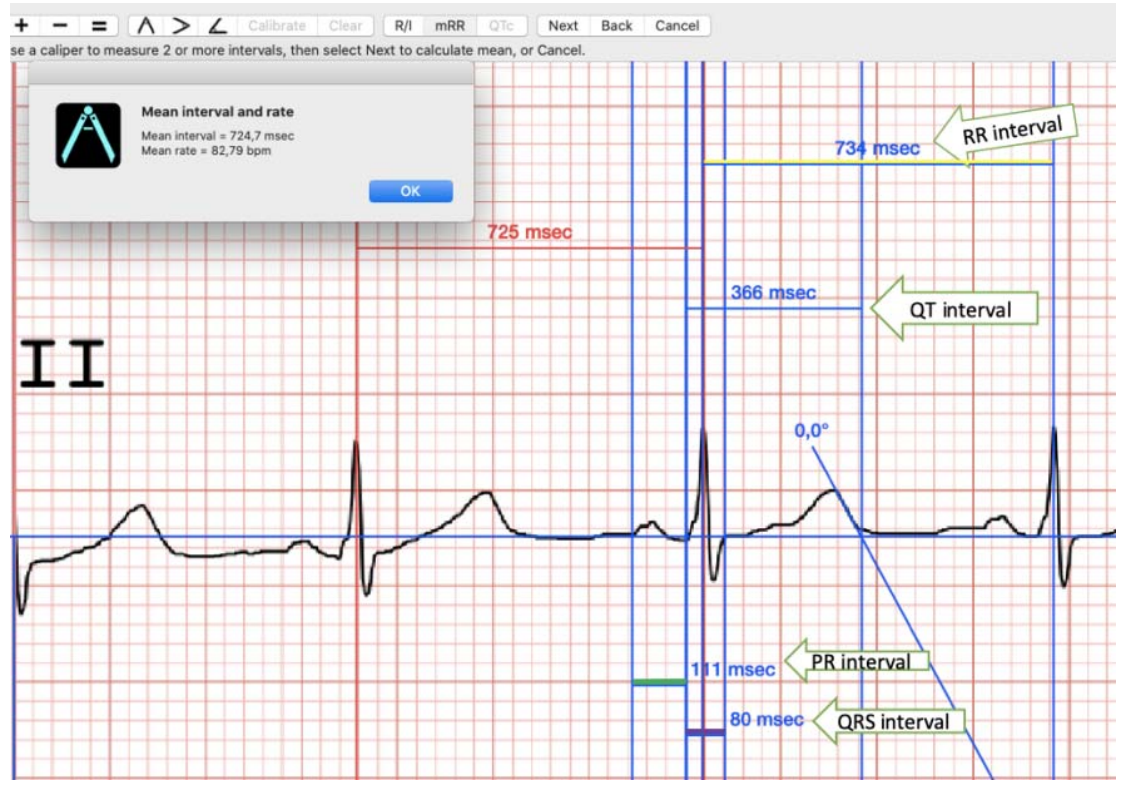


medRxiv preprint doi: https://doi.org/10.1101/2021.02.28.21252516; this version posted March 2, 2021. The copyright holder for this preprint (which was not certified by peer review) is the author/funder, who has granted medRxiv a license to display the preprint in perpetuity.

All rights reserved. No reuse allowed without permission.

\section{$570 \quad$ Supplemental Figure 1: Flowchart}

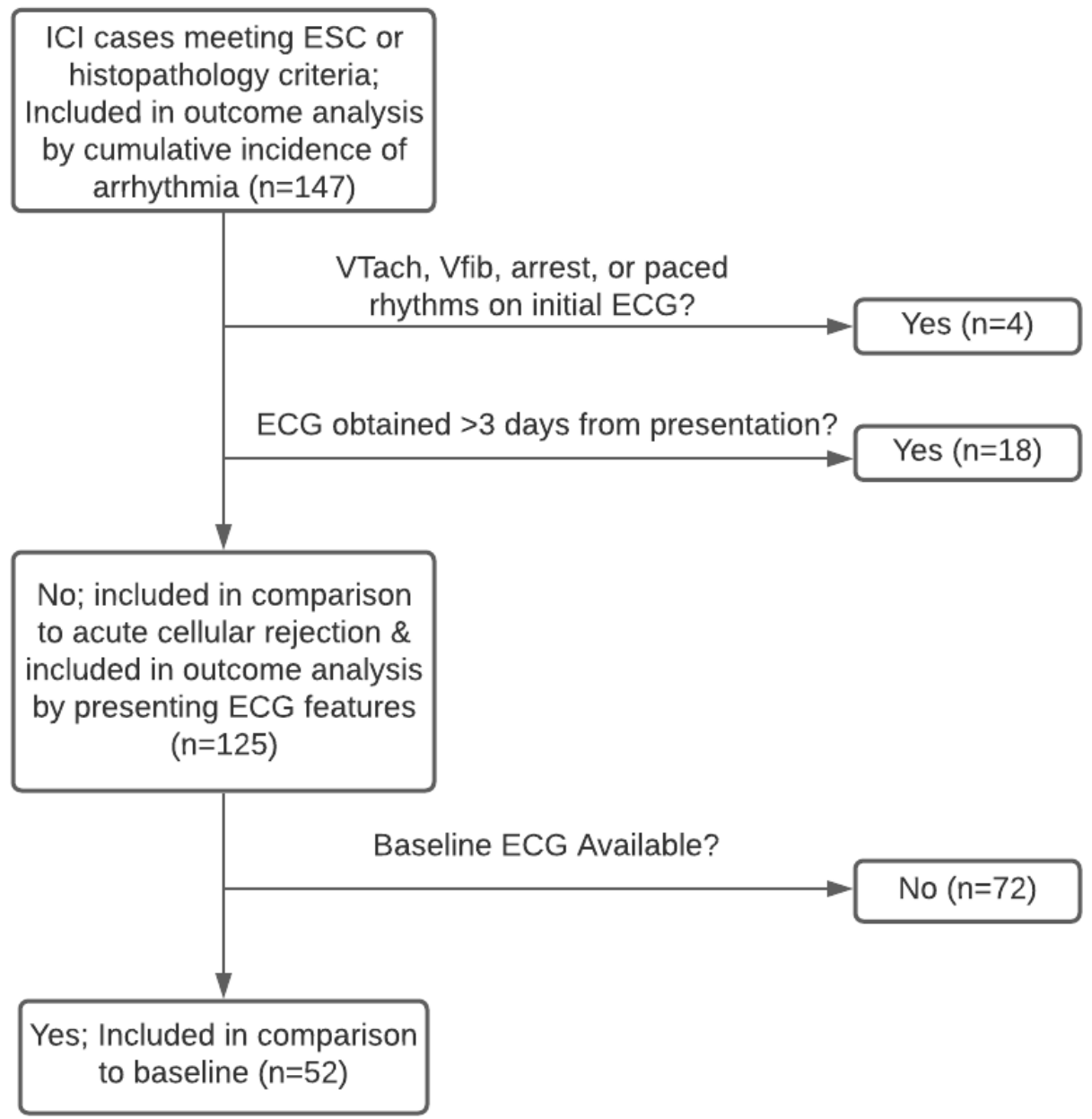


Cumulative incidence of all-cause mortality

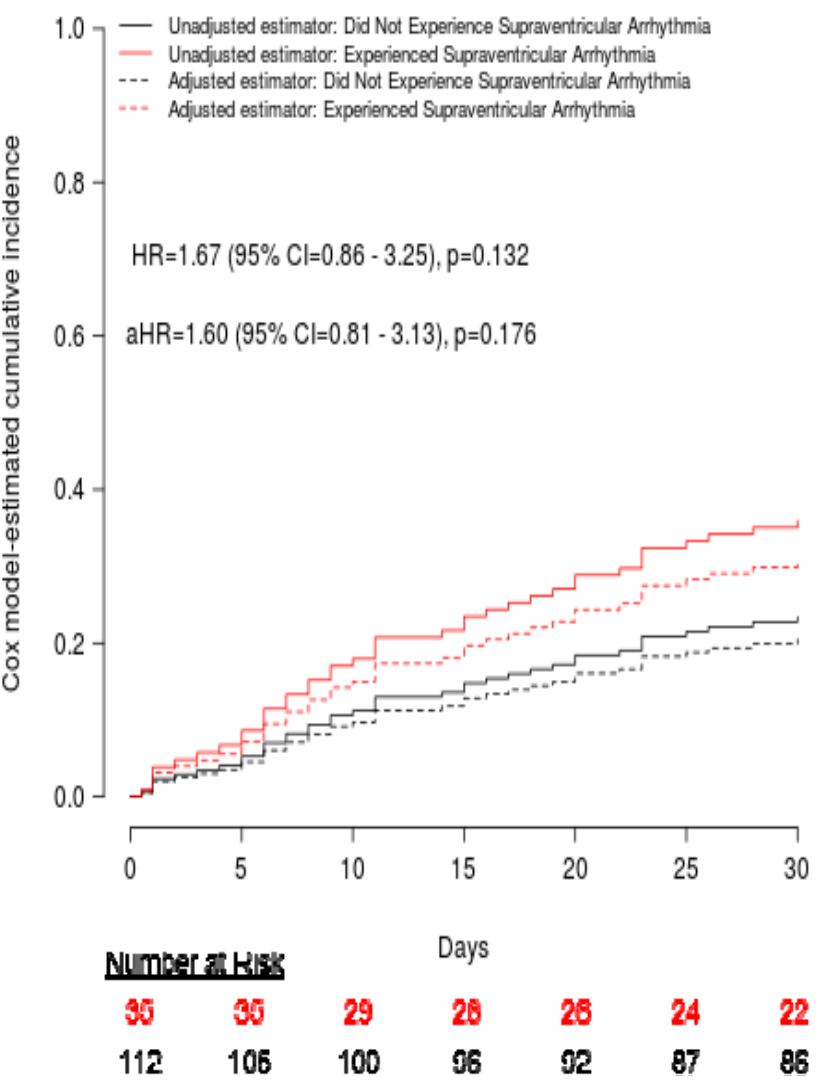

Cumulative incidence of myocarditis-related mortality

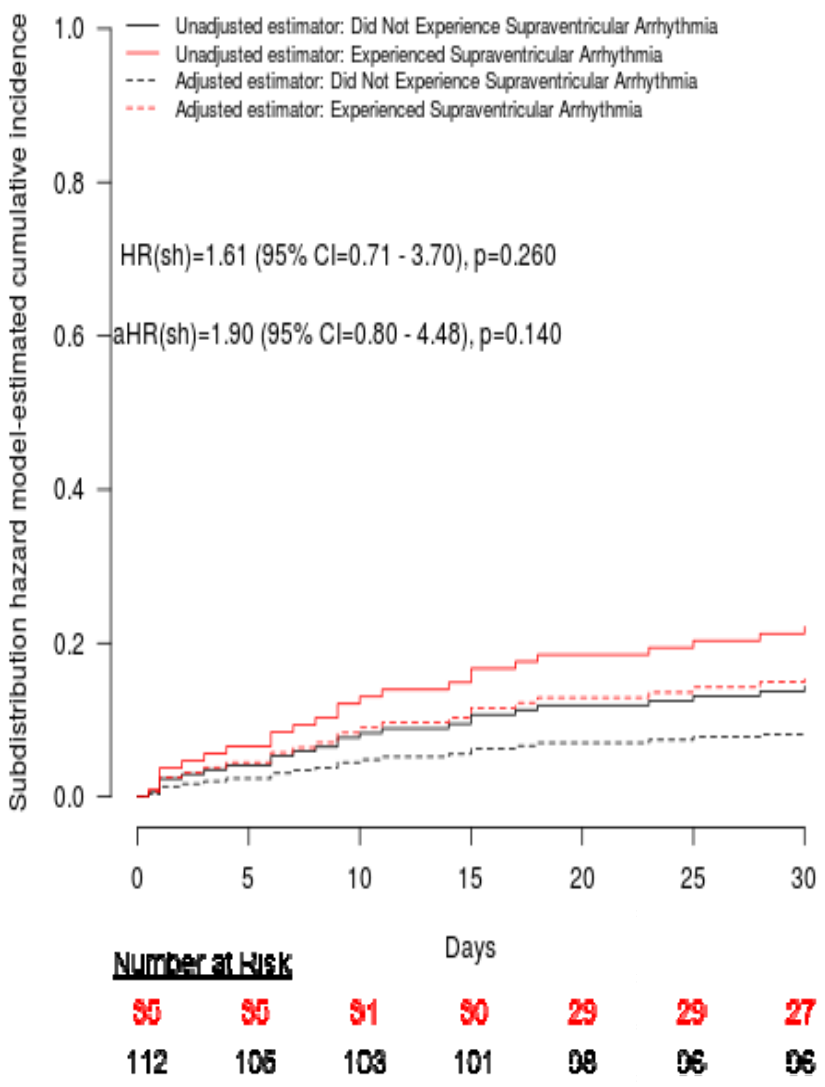

Cumulative incidence of myocarditis-related mortality or life-threatening ventricular arrhythmia

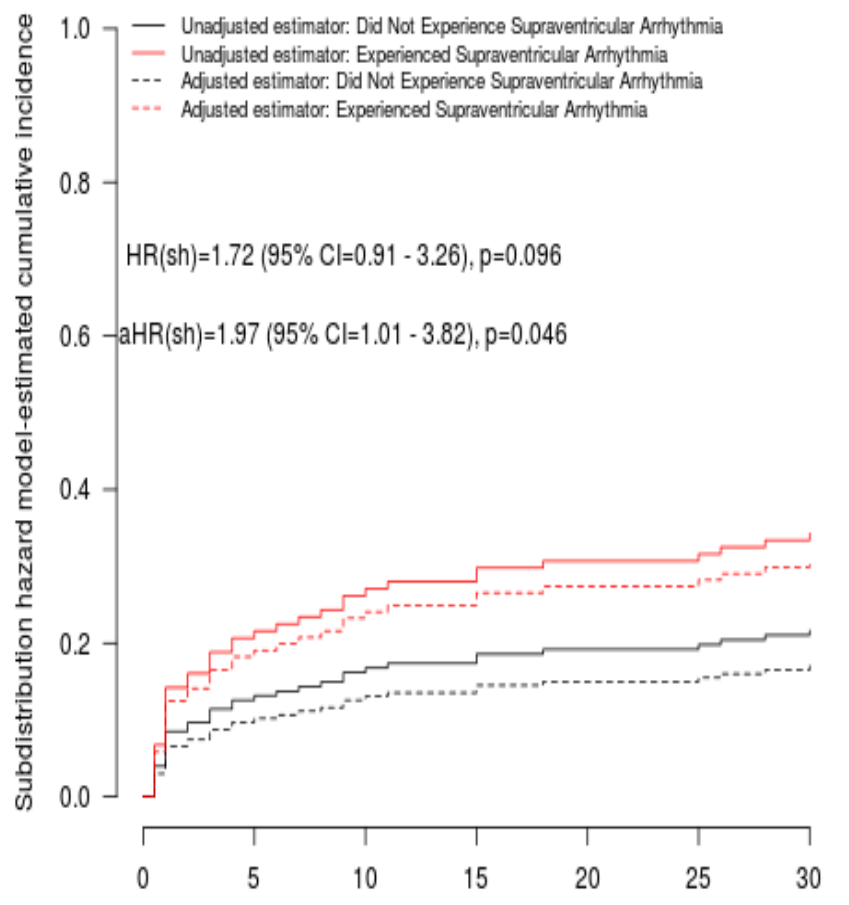

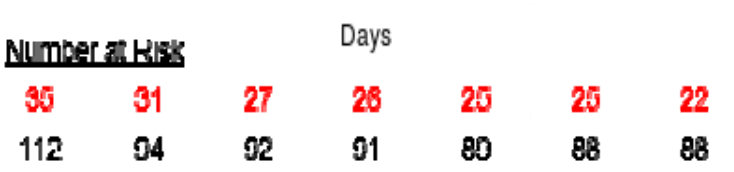


576

577

578

Cox Regression by Sokolow-Lyon Voltage: All-Cause Mortality

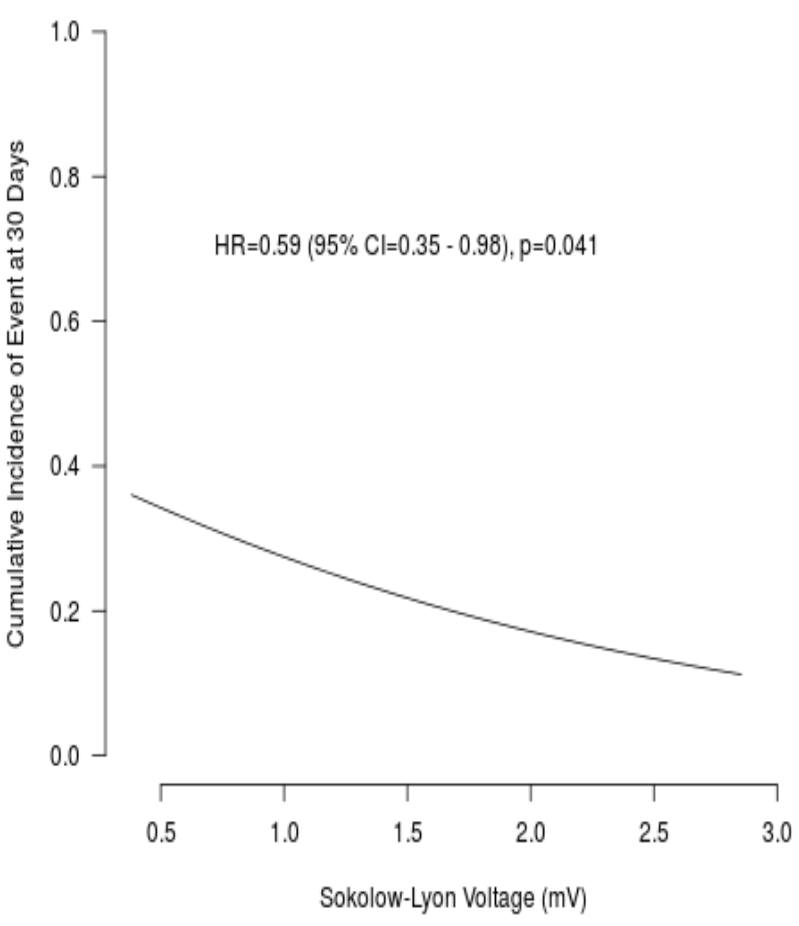

Subdistribution Hazard Regression by Sokolow-Lyon Voltage: Myocarditis-Related Mortality

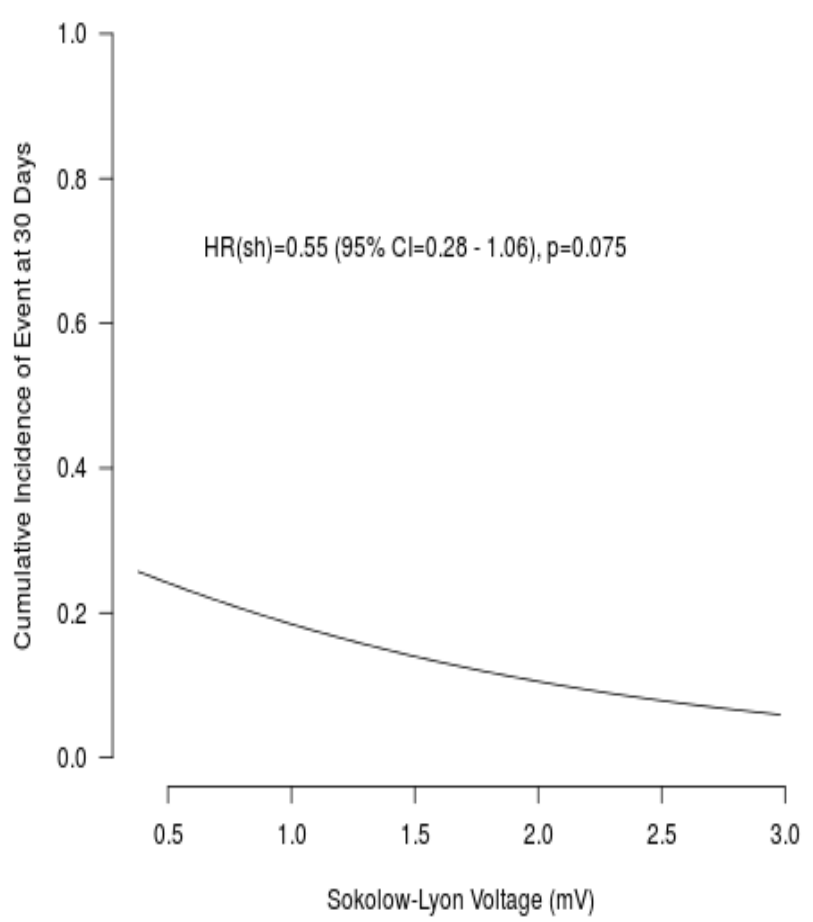

Subdistribution Hazard Regression by Sokolow-Lyon Voltage: Myocarditis-Related Mortality or Life-Threatening Ventricular Arrhythmia

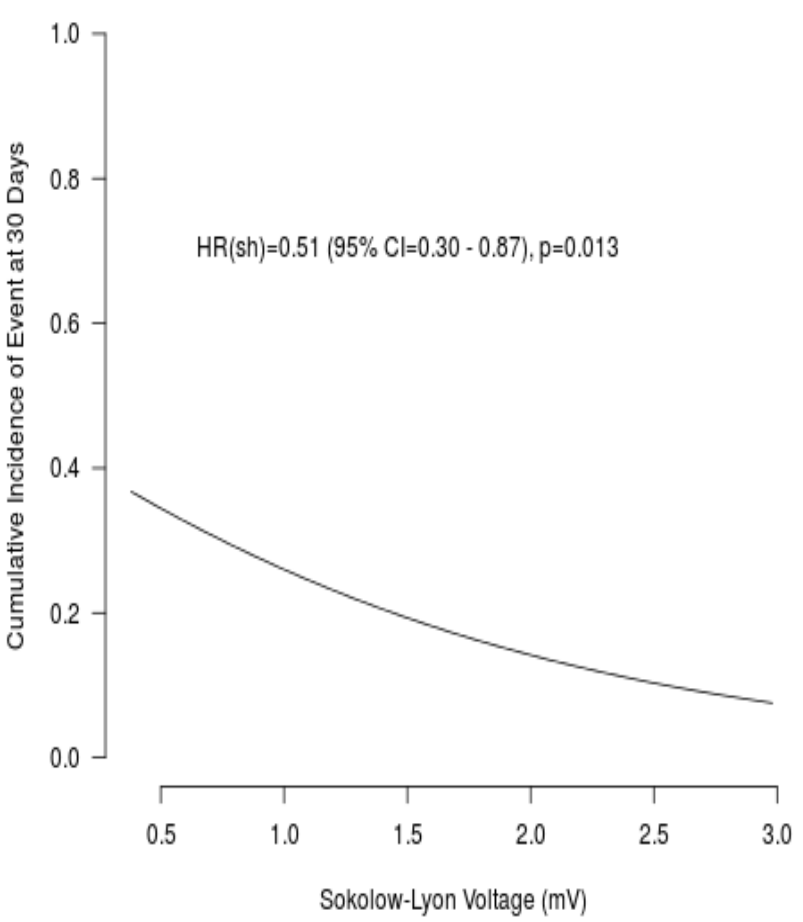



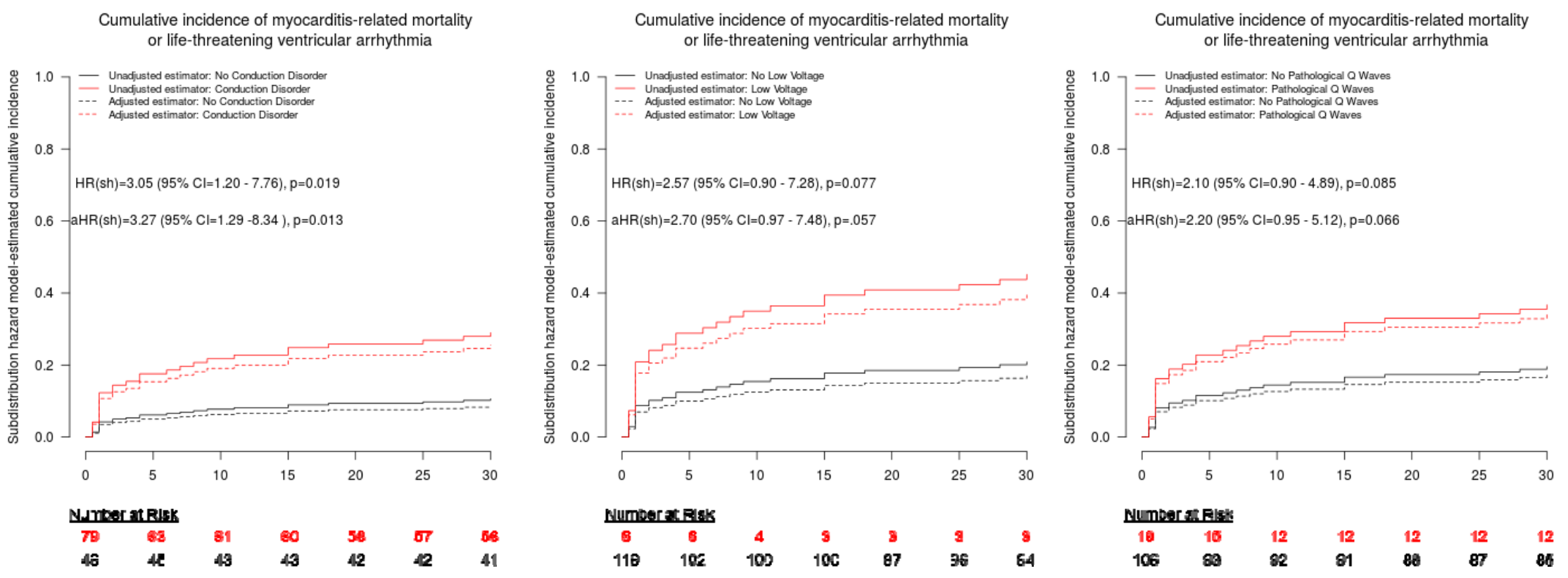

$\begin{array}{ccccccc}10 & 16 & 12 & 12 & 12 & 12 & 12 \\ 106 & 80 & 82 & 81 & 80 & 87 & 86\end{array}$

